\title{
FRAY PEDRO DE JESÚS EN EL PURGATORIO: REESCRITURAS DE UN PASAJE HISTORIOGRÁFICO
}

\author{
POR \\ JoAn Mahiques Climent \\ Programa Beatriu de Pinós \\ (Generalitat de Catalunya - Marie Curie Cofund) \\ Institut National d'Histoire de l'Art (Paris) \\ Groupe d'Anthropologie Historique de l'Occident Médiéval \\ jomahiques@yahoo.es
}

\begin{abstract}
RESUMEN
El segundo volumen de la Reforma de los descalzos (Madrid, 1655) de fray Francisco de santa María refiere que fray Pedro de Jesús, al mismo tiempo que moría en Bellpuig a causa de la peste, se apareció a un compañero en Lleida y le dijo que estaba en el Purgatorio. A partir de diferentes obras y grabados impresos entre los años 1681-1724, estudiamos la relación entre los textos e imágenes que representan este episodio. También editamos dos versiones escritas por fray Juan de san José (1642-1718), cuyos testimonios autógrafos se conservan en los mss. 990 y 991 de la Biblioteca de la Universidad de Barcelona.
\end{abstract}

PALABRAS CLAVE: Purgatorio; apariciones; carmelitas descalzos; ofensas contra el prelado; martirio; peste.

\section{BROTHER PETER OF JESUS AT PURGATORY: REWRITES OF A HISTORIOGRAPHYC PASSAGE}

\begin{abstract}
The second volume of the Reforma de los descalzos (Madrid, 1655) of Brother Francis of St. Mary relates that Brother Peter of Jesus, while dying in Bellpuig because of the plague, appeared to a companion in Lleida to say he was in Purgatory. From different printed works and engravings published from 1681 to 1724, we study the relationship between texts and images representing this episode. We also edit two versions written by Brother John of St. Joseph (1642-1718), whose autographs are preserved in mss. 990 and 991 of the University of Barcelona Library.
\end{abstract}

KEY WORDS: Purgatory; apparitions; discalced carmelites; offenses against the prelate; martyrdom; plague.

Recibido/Received

07-06-2012

Aceptado/Accepted
$13-01-2015$

\section{INTRODUCCIÓN}

Cuando los tres carmelitas descalzos del colegio y convento de San José de Lleida se ofrecieron para asistir a los apestados, la epidemia ya se había extendido por diversas poblaciones de la comarca del Urgell, aunque en ninguna localidad había causado tantos estragos como en Bellpuig. Allí llegaron el día 12 de junio de 1599, y allí morirían poco después, contagiados igual que los enfermos a los que asistían. Fray Pedro de Jesús falleció el 20 de junio, fray Eliseo de San Pedro el 28 del mismo mes, y fray Juan de la Cruz el 6 de julio. Recientemente, hemos estudiado estos sucesos a través de diversas fuentes documentales e historiográficas, entre las cuales destaca sin duda la Información jurídica de los religiosos descalços de Nuestra Señora del Carmen que murieron en la peste de Belpuche. ${ }^{1}$

Conocemos este documento gracias a una transcripción que fray Segismundo del Espíritu Santo (1642-1706) incorporó a sus Monumentos acerca de los sucesos pertenecientes a la

1 Mahiques, Joan 2014a. "Tres carmelites descalços durant la pesta de Bellpuig: reescriptures d'un passatge historiogràfic", Urtx. Revista cultural de l'Urgell 28: 187-204. Mahiques, Joan 2014b. "Tres carmelites descalços durant la pesta de Bellpuig: declaracions jurades", Analecta Sacra Tarraconensia 87: 191-219. 
provincia de los carmelitas descalzos de Cataluña, titulada de San Joseph. ${ }^{2}$ La Información jurídica es la fuente principal de las dos redacciones que escribió fray Juan de San José (16421718), conocido en este siglo con el nombre de Joan Blanc i Mur, cuyos testimonios autógrafos se han conservado en los mss. 990 y 991 de la Biblioteca de la Universidad de Barcelona. ${ }^{3}$

Podemos suponer que la versión más antigua es la copiada en el ms. 990, que transmite la Historia de la provincia de San Joseph de los carmelitas descalços en el Principado de Cathaluña. El ms. 991 tiene un colofón escrito en Mataró el 8 de agosto de 1707, y una portada con el siguiente título: Annales de los carmelitas descalços de la provincia de San Josef en el Principado de Cathaluña. Quisiéramos recordar, a manera de síntesis, los capítulos de cada una de ellas: ${ }^{4}$

\footnotetext{
2 Fundamental para el estudio de los carmelitas en Cataluña es esta obra de fray Segismundo del Espíritu Santo, que podríamos considerar una miscelánea documental más bien que una crónica historiográfica. Se ha conservado el mismo volumen que preparó su autor, eso es el ms. 992 de la Biblioteca de la Universidad de Barcelona. La Información jurídica reúne diversos documentos y declaraciones que datan del 21 al 24 de diciembre de 1626, prácticamente todos en Bellpuig, y fue publicada por Ripoll Villamajó, Jaume 1820. Compendio de la vida y virtudes del ven. P. Fr. Juan de la Virgen, carmelita descalzo natural de la villa de Bellpuig, $y$ de otros tres carmelitas descalzos que dieron sus vidas asistiendo a los apestados de la misma villa: sacado de los Anales $\mathrm{mm}$. de los pp. carmelitas descalzos de Cataluña, y publicado con algunas notas por $D$. J. R. V.: 43-58. Vic: Ignacio Valls. Entre los diversos testimonios, destaca claramente la figura del presbítero Josep Janer, cuyas declaraciones (como observaremos más adelante en reiteradas ocasiones) son la base de diversos pasajes de autores como fray Francisco de Santa María o fray Juan de San José. La Información jurídica, y otras declaraciones conservadas en los mss. 3537 y 5631 de la Biblioteca Nacional de España, han sido editadas por Mahiques, Joan 2014b.
}

3 A partir de ahora nos referiremos a los mss. 990, 991 y $992 \sin$ necesidad de indicar la biblioteca a la cual pertenencen. Adviértase que tanto fray Segismundo del Espíritu Santo como fray Juan de San José fueron cronistas de la provincia de San José. Se trata de dos autores estrictamente coetáneos, pues ambos nacieron en el mismo año. El segundo sucedió al primero en el cargo de historiador de la provincia. De hecho, los Monumentos de fray Segismundo copiados en el ms. 992 comienzan con "una carta-prólogo del autor al P. Fr. Juan de San José, el segundo cronista catalán, y en ella explica el desarrollo de la obra" (Arnall Juan, M. a Josepa 1986. "Aportación de los carmelitas descalzos a la cultura catalana", en El Carmelo teresiano en Cataluña. 1586-1986: 89. Burgos: Monte Carmelo). En el mismo estudio se añade más adelante, refiriéndose a la labor de fray Juan de San José y al ms. 991 de la BUB: "Cuando la Provincia, ya separada de Aragón y Valencia, determinó escribir su historia propia, nombró historiador a Fr. Segismundo del Espíritu Santo, pero en 1695 el mismo P. Blanch se puso a escribir a modo de crónica los principales acontecimientos de la descalcez catalana y en 1707 concluía en Mataró su gran obra que tituló: Annales de los Carmelitas Descalzos de la Provincia de San Joseph en el Principado de Cataluña" (Ibídem: 90). Puede consultarse una biografía de ambos cronistas en Gras Casanovas, Mercè 2014. Diccionari biogràfic d'autors carmelites descalços de la Província de Sant Josep, en MCEM (Base de dades de Manuscrits Catalans de l'Edat Moderna). Barcelona: Institut d'Estudis Catalans. <http://mcem.iec.cat/ biografia.asp?id=64><http://mcem.iec.cat/biografia.asp?id=150> (fecha de consulta: 20/12/2014). Los mss. 990, 991 y 992 han sido descritos en las siguientes obras bibliográficas: Miquel Rosell, Francisco 1958. Inventario general de manuscritos de la Biblioteca Universitaria de Barcelona. II: 501 a 1000: 563-568. Madrid: Direcciones Generales de Enseñanza Universitaria y de Archivos y Bibliotecas / Servicio de Publicaciones de la Junta Técnica. Duran, Eulàlia dir. / Toldrà, Maria coord. 2012. MCEM (Base de dades de Manuscrits Catalans de l'Edat Moderna): núm. 1165, 1166 y 1187. Barcelona: Institut d'Estudis Catalans. <http://mcem.iec.cat/> (fecha de consulta: 05/04/2012).

4 De las diferencias existentes entre las redacciones de ambos manuscritos nos hemos ocupado en Mahiques, Joan 2014a.

\begin{tabular}{|c|c|}
\hline Ms. 990, libro IV & Ms. 991, libro II \\
\hline $\begin{array}{l}\text { Capítulo XVII. Entra la peste en } \\
\text { la villa de Bellpuig y acuden a } \\
\text { su asistencia tres religiosos de } \\
\text { Lérida }\end{array}$ & $\begin{array}{l}\text { Capítulo XXXXV. Entra la peste } \\
\text { en la villa de Bellpuyg y acuden } \\
\text { a su asistencia tres religiosos de } \\
\text { Lérida }\end{array}$ \\
\hline $\begin{array}{l}\text { Capítulo XVIII. Mueren los tres } \\
\text { dichos religiosos sirviendo en } \\
\text { sus ministerios, y cessa la peste }\end{array}$ & $\begin{array}{l}\text { Capítulo XXXXVI. Mueren los } \\
\text { tres religiosos y cessa la peste }\end{array}$ \\
\hline $\begin{array}{l}\text { Capítulo XIX. Aparécese el } \\
\text { hermano fray Pedro de Jesús } \\
\text { diziendo estava en el Purgatorio, } \\
\text { y pondéranse algunos reparos }\end{array}$ & $\begin{array}{l}\text { Capítulo XXXXVII. Aparécese el } \\
\text { hermano fray Pedro de Jesús } \\
\text { diziendo estava en Purgatorio }\end{array}$ \\
\hline $\begin{array}{l}\text { Capítulo XX. Esplícase la apari- } \\
\text { ción y cessan todos los reparos }\end{array}$ & \\
\hline
\end{tabular}

El motivo de estudio de nuestro artículo se centra principalmente en la aparición de fray Pedro de Jesús, relatada en los capítulos XIX-XX del ms. 990 y XXXXVII del ms. 991. A diferencia de lo que sucede en los demás capítulos de la tabla precedente, estos pasajes han permanecido inéditos hasta el día de hoy. ${ }^{5}$ De todos modos, la noticia de fray Pedro de Jesús en el Purgatorio la encontramos en algunas fuentes impresas del siglo XVII, anteriores a fray Juan de San José. Así sucede en el capítulo XXX del libro VIII del segundo volumen de la Reforma de los descalzos, de Francisco de Santa María. ${ }^{6}$ Este relato, que incluye tanto lo sucedido durante la peste de Bellpuig como la aparición de fray Pedro de Jesús justo en el momento de su muerte, fue retomado casi literalmente en la cuarta de las Cinco palabras del apóstol san Pablo, de Francisco de la Cruz. ${ }^{7}$ A continuación, nos ocuparemos de estas obras impresas, para pasar más adelante a las diferentes reescrituras de los mss. 990 y 991.

\section{El PURgatorio de fRAY PEdRo en LA tRADICIÓN IMPRESA: TEXTO E IMAGEN}

Como ya hemos indicado, la cuarta de las Cinco palabras -eso es credenda- de Francisco de la Cruz sigue muy de cerca el relato de fray Francisco de Santa María. ${ }^{8}$ Es verdad que, en relación a este modelo, la primera obra opera algunos cambios significativos, sobre todo a la hora de seleccionar los pasajes, ya que, en lugar de relatar la historia de los tres carmelitas, se centra solamente en la figura de uno de

Los capítulos XVII-XVIII (ms. 990, libro IV) y XXXXV-XXXXVI (ms. 991, libro II) cuentan con una edición sinóptica de Mahiques, Joan 2014a. Previamente, los dos capítulos del ms. 991 ya fueron publicados por Ripoll Villamajó, Jaume 1820: 29-43, y Puig, Isidre / Company, Ximo 2009. Els carmelites descalços a Lleida. El convent de Sant Josep: 148152, § 605-613. Lleida: Museu de Lleida.

Francisco de Santa María 1655. Reforma de los descalzos de Nvestra Señora del Carmen de la primitiva observancia, hecha Por santa Teresa de lesvs en la antiquissima Religion fundada por el gran Profeta Elias. Al eminentissimo i reverendissimo señor Cardenal D. Baltasar de Moscoso i Sandoval, Arçobispo de Toledo, \&c. Por el Padre Fray Francisco de Santa Maria su General Historiador, natural de Granada. Tomo Segundo: 517-519, § 13-15. Madrid: Diego Diaz de la Carrera.

7 Francisco de la Cruz 1681. Quarta palabra. Credenda. Aplicada al Purgatorio: 428-433, § 12.1. Nápoles: Marco Antonio Ferro.

8 Ibídem: 428-433, § 12.1 . 
ellos, fray Pedro de Jesús, que al mismo tiempo que murió en Bellpuig se apareció en Lleida a otro carmelita, explicándole que estaba en el Purgatorio. Esta alteración, que se evidencia sobre todo en el breve pasaje que citamos a continuación, concuerda perfectamente con la temática de la palabra credenda, aplicada a las ánimas de los difuntos que todavía están en proceso de purificación:

I repartiendo entre sí las ocupaciones, cupo al padre vicerector el de administrar los sacramentos i ayudar a los agonizantes, al hermano fray Pedro el curarlos, el enterrarlos i hazer las sepolturas, al padre fray Eliseo darles de comer i prevenir lo necessario de medicinas, regalos i lo demás que perteneciesse a su salud. ${ }^{9}$

En lo referente a la vida y la muerte de fray Pedro de Jesús, ambas versiones son casi idénticas, aunque Francisco de la Cruz omite igualmente un par de fragmentos de la crónica de Francisco de Santa María. Citamos esta última versión marcando en cursiva los pasajes que faltan en las Cinco palabras:

El que más en esto se adelantó fue el hermano fray Pedro, porque no contentándose con gastar el día en curar los enfermos, traer en sus ombros los difuntos, empleava las noches en desenterrar muchos de los ya enterrados que por someros en la tierra inficionavan el ayre i en darles más hondas i eclesiásticas sepolturas. Picávale tanto en esta parte el zelo que, representando al regimiento quán indecente era que cuerpos de católicos estuvieran fuera de sagrado i acinados en un silo donde muchos avían sido puestos, se obligó a sacarlos i trasladarlos a un cementerio. Començó dos vezes la obra, pero el hedor de los ya corrompidos fue tal que le estorbó el proseguirla. Hiriose antes de los ocho días y, llegándole a visitar la noche de su muerte el sacerdote que les asistía, le halló derramando lágrimas. Pensando ser de pena, le consoló con el cercano galardón. I rehaziéndose el enfermo, le dixo: "No son, señor, mis lágrimas por morir i perder la vida, que para esto la quiero, sino por no tener otras muchas que ofrecer en servicio de Dios i d'estos pobres i desamparados huérfanos". Cuyas palabras le arrancaron el alma a 20 de junio. Estando a la misma hora en Lérida el hermano Joseph de la Madre de Dios, religioso de aprobada santidad, le vio entrar en su celda $y$, tomando agua bendita, hazer una profunda inclinación a una santa Verónica que en ella tenía. Turbose algo i, animándole el difunto, dixo: "Yo soi el hermano fray Pedro de Jesús, que en esta hora acabo de espirar en Belpuch. Pide perdón al padre rector de mi parte del poco sufrimiento i humildad con que llevé la reprehensión que tal día me hizo en secreto, porque por ella estoy en Purgatorio, i no saldré hasta que en el sacrificio de la missa ruegue por mí". | ${ }^{519 a}$ Desapareció con esto i, dando qüenta el hermano Joseph al prelado, se acordó él de la falta. Lebantose en amaneciendo, díxole missa i, haziendo que otros también se la dixeran, tuvo por cierto haverse ido a gozar de Dios. Raro es este caso i significativo grandemente del rendimiento humilde con que el Señor nos quiere en las correcciones, pues a varón que tanto hizo i tanto se empeñó por su amo

\footnotetext{
9 Francisco de Santa María 1655: 518
}

10 Francisco de la Cruz 1681: 430 no perdona ni dexa sin castigo culpa que apenas lo parece a nuestros flacos ojos. ${ }^{11}$

Aunque el texto de fray Francisco de la Cruz no deja de ser una mimética reiteración del que acabamos de citar, los grabados incorporados en algunas de las ediciones de la Cuarta palabra, credenda otorgan un valor iconográfico añadido al episodio de fray Pedro de Jesús en el Purgatorio. ${ }^{12}$

Tal como podemos observar en la primera ilustración que acompaña a este artículo, las ediciones napolitanas de 1681 y 1682 transmiten una estampa que bajo el mismo marco representa escenas de la vida de tres carmelitas distintos, identificados como fray Tomás de Jesús, fray Pedro de Jesús y la madre Juana Bautista de Santa Teresa, tal como indican las tres viñetas que figuran en el margen inferior. La parte inferior de la estampa dibuja dos espacios relativos a la vida y la muerte de fray Tomás de Jesús: por una parte, un eremitorio, ya que este religioso fue el fundador de los primeros desiertos de carmelitas descalzos; por otra parte, el coro, donde el mismo fray Tomás se apareció a fray Domingo de Jesús anunciándole que abandonaba las penas del Purgatorio. En el margen superior derecho del grabado, bajo una arcada, se sitúa el tercer protagonista, es decir la madre Juana Bautista de Santa Teresa. A diferencia de los demás ejemplos, esta no es representada como ánima difunta sino como intercesora por estas. El ángulo superior izquierdo escenifica la Gloria celestial mediante una nube, en cuyo centro están un ángel y otra figura que parece identificarse con Jesucristo. Este espacio no parece estar asociado exclusivamente a uno de los tres personajes de la estampa, sino más bien a todos ellos, que de hecho tienen la seguridad de alcanzar la visión beatífica.

Tres escenas distintas de fray Pedro de Jesús están imbricadas en el centro de este grabado. En la primera lo vemos convaleciente, tendido sobre un lecho y pronunciando un mensaje ("Iloro el no poder assis- | tir á estos nececita- | dos.") que sintetiza las palabras que pronunció justo antes de morir. A su lado aparecen dos lechos de tamaño inferior ocupados por apestados de Bellpuig. La segunda escena refiere su aparición en Lleida justo en el mismo momento

11 Francisco de Santa María 1655: 518 b $-519^{a}$. Cf. Francisco de la Cruz 1681: 431-433.

12 Esta obra circuló a través de ediciones tanto en castellano como en italiano que señalaremos en las notas que acompañan a las tres figuras reproducidas en este artículo. Muchas de las ediciones las hemos consultado a través de ejemplares de la Biblioteca de Catalunya que pertenecieron a Eduard Toda i Güell. También hemos recibido la información bibliográfica necesaria de diversas bibliotecas con ejemplares de las ediciones impresas en italiano en 1691 y 1711 , que no hemos consultado personalmente: expresamos nuestro agradecimiento al personal de la Biblioteca provinciale Tommaso Stigliani de Matera, la Biblioteca centrale della Regione siciliana Alberto Bombace de Palermo y la Biblioteca nazionale Sagarriga Visconti-Volpi de Bari. La difusión de la obra de Francisco de la Cruz, en castellano y en italiano, ha sido estudiada por Toda y Güell, Eduart 1928. Bibliografia espanyola d'Italia dels origens de la imprempta fins a I'any 1900 per Eduart Toda y Güell. Volum II: D-L: 116-119, núm. 1797-1805. Castell de Sant Miquel d'Escornalbou: [Imp. Vidal Güell]. Palau y Dulcet, Antonio 1967. Manual del librero hispanoamericano. Bibliografía general española e hispanoamericana desde la invención de la imprenta hasta nuestros tiempos con el valor comercial de los impresos descritos. Segunda Edición, corregida y aumentada por el autor. Tomo XIX: San - Santa (289221-299369): 201-202, núm. 293269293278. Barcelona: Librería Palau. 
de morir en Bellpuig. Entre llamas y con las manos juntas en actitud de oración, el difunto dice al visionario: "en la | Missa | ruega | por mi". En la tercera escena, el fraile sigue tendido sobre el lecho, pero está rodeado de dos ángeles, lo cual indica que el moribundo acaba de abandonar la vida mortal y está predestinado a la bienaventuranza. Es muy significativa la posición que ocupan estas tres secuencias en la imagen. Sin ningún elemento arquitectónico que las separe, de la primera a la tercera se nota un movimiento ascendente en consonancia con la semántica que se desprende de cada una de ellas: la muerte, el Purgatorio y la Gloria. Aunque tienen un orden claramente establecido desde el punto de vista lógico, pues la primera desencadena la segunda, y la segunda la tercera, no sucede exactamente lo mismo en el plano temporal, en el que las tres acciones podrían considerarse sincrónicas.

Sin duda, se inspira en esta estampa otra bastante similar, que reproducimos en la figura 2 , impresa en tres ediciones napolitanas de 1687, 1691 y 1711 . Más que el uso del italiano en lugar del castellano, la principal diferencia que salta a la vista es la evidente proliferación de personajes y concentración de escenas en el poco espacio disponible. La leyenda situada en el margen inferior de este grabado menciona seis personajes que las ediciones precedentes en castellano distribuían en dos estampas, cada una de ellas con tres sucesos diferentes. En efecto, a los casos arriba mencionados, ahora se añaden otros tantos. En el margen superior, un ánima difunta confirma la sentencia de un santo obispo, que aseguraba el ciento por uno por un acto de limosna. Las otras dos anécdotas se ubican a ambos lados del relato de fray Pedro de Jesús. A la izquierda, fray Domingo de Jesús María está ante el altar, desdoblado en dos figuras que lo representan primero arrodillado en oración y después oficiando una misa donde ve a las ánimas del Purgatorio que se salvan en virtud del sacrificio eucarístico. Aunque este desdoblamiento se identifica nítidamente en otro grabado anterior (que no reproducimos aquí) inserto en las ediciones de 1681 y 1682, dicha identificación es menos evidente en la estampa que ahora nos ocupa, y todavía quedará más desdibujada en el impreso valenciano de 1724 , donde los rostros de ambas figuras tienen fisonomías diferentes.

Si volvemos a la figura 2, a la derecha de la historia de fray Pedro de Jesús vemos a fray Elías de San Francisco, que se aparece a un reverendo padre provocando la sana envidia de este. En este último caso, la representación iconográfica parece centrarse solamente en la entrada del difunto a la Gloria, poniendo en boca de este un saludo ("Salue I Reuerende ( Pater") que el texto de Francisco de la Cruz contextualiza no al salir de las penas temporales sino en pleno proceso de purificación. Además, aunque ocupando un puesto marginal, el visionario de este caso está integrado en el mismo coro en el que fray Tomás de Jesús se aparece a fray Domingo de Jesús. Dicho de otro modo, dos relatos diferentes son parcialmente escenificados en el mismo lugar.

Si nos centramos en la figura de fray Pedro de Jesús, la estampa en italiano reduce el número de lechos, ya que únicamente están tendidos el fraile carmelita y, a su izquierda, un apestado. Además, solo se reproducen con claridad la primera y la segunda de las tres secuencias superpuestas que encontrábamos en las ediciones anteriores, ya que la tercera escena, donde dos ángeles acompañan a un moribundo, añade una leyenda escrita que poca relación guarda con el caso concreto de fray Pedro. A nuestro modo de ver, el grabado impreso entre 1687 y 1711 ha cambiado el contexto de esta última escena, que ahora se atribuye no a fray Pedro sino a fray Domingo de Jesús María. De todos modos, planteamos esta última interpretación como mera hipótesis.

No menos interesante desde el punto de vista iconográfico es otra edición (Valencia, 1724), que transmite la estampa reproducida en la figura $3 .{ }^{13}$ En ella se representan cuatro historias diferentes, introducidas cada una de ellas en una de las viñetas que figuran en el margen inferior, a las cuales se ha asignado una de las cuatro primeras letras del abecedario. Los espacios de cada uno de los relatos en cuestión están nítidamente compartimentados a partir de los elementos arquitectónicos y de las secciones cuadradas o rectangulares donde se enmarca cada caso. Este aspecto diferencia claramente esta estampa de las figuras 1 y 2 , ya que en estas últimas las escenas no están circunscritas a ningún marco, y raramente presentan algún elemento arquitectónico que permita separar los espacios de cada relato. La persona que observa los grabados napolitanos ha de hacer un esfuerzo añadido para separar e interpretar cada uno de los casos, que a nuestro modo de ver no pueden ser descifrados cabalmente sin la ayuda del texto de Francisco de la Cruz que acompaña a las imágenes. De hecho, en todas las ediciones de las Cinco palabras que acabamos de comentar, los grabados no son autónomos desde el momento en que su comprensión requiere el conocimiento previo de cada trama argumental.

Aparte del estilo y de la distribución del espacio, otra divergencia notable entre la estampa valenciana y las figuras 1 y 2 puede explicarse a través del texto que acompaña a la imagen. Si volvemos al caso de fray Pedro de Jesús, podríamos decir que las ediciones napolitanas ponen énfasis en el solidario intercambio de beneficios entre vivos y difuntos: convaleciente, fray Pedro manifiesta el deseo de entregar su única vida y cuantas tuviese por asistir a los apestados; muerto y en proceso de purificación, manifiesta el poder salvífico del sacrificio de la misa que los vivos pueden aplicar en sufragio de los difuntos.

En cambio, la figura 3 presenta a fray Pedro confesando que, por su propia culpa, padece tales penas, a lo cual responde el visionario asegurando que avisará al padre rector del colegio y convento de Lleida. De esta manera se acentúa la responsabilidad personal del difunto en relación a sus pecados, remitiéndose además indirectamente al rector, precisamente la autoridad cuyo honor habría lesionado, con su pecado de desobediencia, fray Pedro de Jesús. Este punto de vista teológico y moral, que indaga en la culpa y en su relación con la pena sufrida en el Purgatorio, será desarrollado ampliamente por fray Juan de San José, tal como observaremos más adelante.

En todas las ediciones comentadas, tanto las napolitanas como la valenciana, abundan los grabados donde las

13 Los grabados esta edición valenciana han suscitado el interés de Carrete Parrondo, Juan / Checa Cremades, Fernando / Bozal, Valeriano 1987. Summa Artis. Historia general del arte. Vol. XXXI: EI grabado en España (siglos XVI al XVIII): 301. Madrid: Espasa-Calpe. 
apariciones de difuntos se relacionan directamente con el culto de las almas del Purgatorio, cuya inconfundible gestualidad, acompañada de otros elementos figurativos o textuales, facilitan la correcta interpretación de cada uno de los ciclos figurados. Tal como ya hemos sugerido, y de acuerdo con una tradición iconográfica perfectamente establecida en el siglo XIV, las ánimas en proceso de purificación suelen estar rodeadas de fuego, orando con las manos juntas, con un rostro sufriente pero sereno y confiado. Se trata de una representación estática, concorde a la creencia en el rigor con que las faltas e imperfecciones son tomadas en el Purgatorio. En cambio, el acceso a la Gloria es captado en pleno movimiento, como fray Elías de San Francisco en la figura 2 o fray Tomás de Jesús en la figura 3. A diferencia de estos dos casos, donde los protagonistas ascienden solos a la bienaventuranza, en otros grabados de la misma obra entran en escena ángeles que tienden las manos parar sacar a las ánimas purificadas y subirlas a la Gloria. Sin embargo, no sucede así ni en las tres imágenes que reproducimos ni tampoco en la mayor parte de los grabados de la Cuarta palabra, credenda.

En las estampas que hemos analizado, como en el resto de las que ilustran las Cinco palabras, los espacios de ultratumba no forman una cosmología completa, como podríamos encontrar en los retablos o frescos medievales sobre el Juicio Final, donde Infierno, Purgatorio, Gloria y limbo de los niños no bautizados solían integrarse en una lógica representación topográfica del más allá. ${ }^{14}$ Esta diferencia es perfectamente comprensible si tenemos en cuenta que la obra de Francisco de la Cruz atiende de manera especial a los hechos memorables de carmelitas descalzos, organizando en volúmenes distintos los diferentes destinos de ultratumba. Tal como hemos indicado, el caso de fray Pedro de Jesús se incluye en la palabra cuarta, credenda, referente al Purgatorio. Las otras palabras temáticas son agenda, timenda, vitanda y speranda, que se aplican respectivamente a la muerte, al Juicio, al Infierno y a la Gloria. Si a nivel conceptual se completa de este modo todo un ideario espiritual fundamentado en las postrimerías, desde el punto de vista plástico se modelan sobre todo venerables figuras de carmelitas descalzos, aunque las representaciones simbólicas o escenográficas sobre el más allá no están totalmente ausentes: son especialmente visibles en el primer grabado de cada volumen o palabra.

Finalmente, debemos destacar que las estampas de las Cinco palabras sí que plasman una realidad compleja a través de la superposición de varias historias ejemplares. A nivel iconográfico, existe una relación de influencia entre las figuras reproducidas en este artículo, ya que las más tardías parecen tener en cuenta a las precedentes, pero también se produce una progresiva reinterpretación que conlleva algunas divergencias notables, hasta el punto de apuntar una lectura distinta de los respectivos casos paralelos.
FIGURA 1

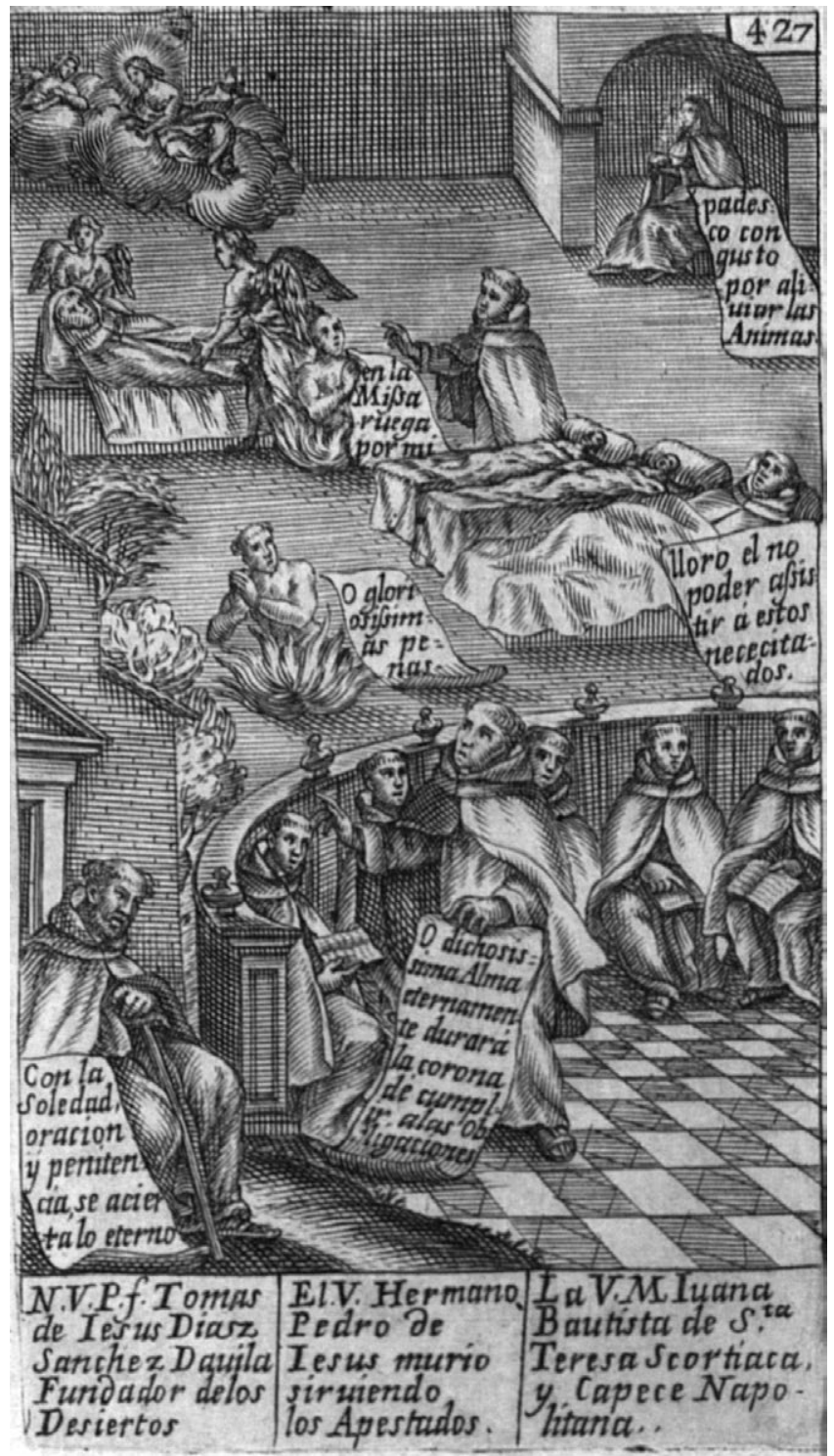

Francisco de la Cruz 1681. Qvarta palabra. Credenda. Aplicada al Purgatorio. Se dedica por el Autor a las benditas animas. Nápoles: Marco Antonio Ferro. Estampa de $125 \times 70 \mathrm{~mm}$, grabada en el verso de un folio inserto entre las p. 426 y 427 del volumen, que reproducimos a partir de un ejemplar de la Biblioteca de Catalunya [signatura: Toda 8-III-12]. Este mismo grabado, pero con diferente guarismo al margen superior derecho ("442" en lugar de " 427 ") fue impreso un año después en otra edición napolitana que conocemos a través de un ejemplar de la Biblioteca de Catalunya [signatura: Toda 8-III-13]: Francisco de la Cruz 1682. Quarta palabra. Credenda. Aplicada al Purgatorio Nápoles: Marco Antonio Ferro.

14 Baschet, Jerôme 1993. Les justices de l'au-delà. Les représentations de l'enfer en France et en Italie (XIle-XVe siècle). Roma: École Française de Rome. Fournié, Michelle 1997. Le ciel peut-il attendre. Le culte du Purgatoire dans le Midi de la France (1320 environ - 1520 environ). Paris: Cerf. Rodríguez Barral, Paulino 2007. La justicia del más allá. Iconografía en la Corona de Aragón en la Baja Edad Media. Valencia: Universitat de València. 
FIGURA 2

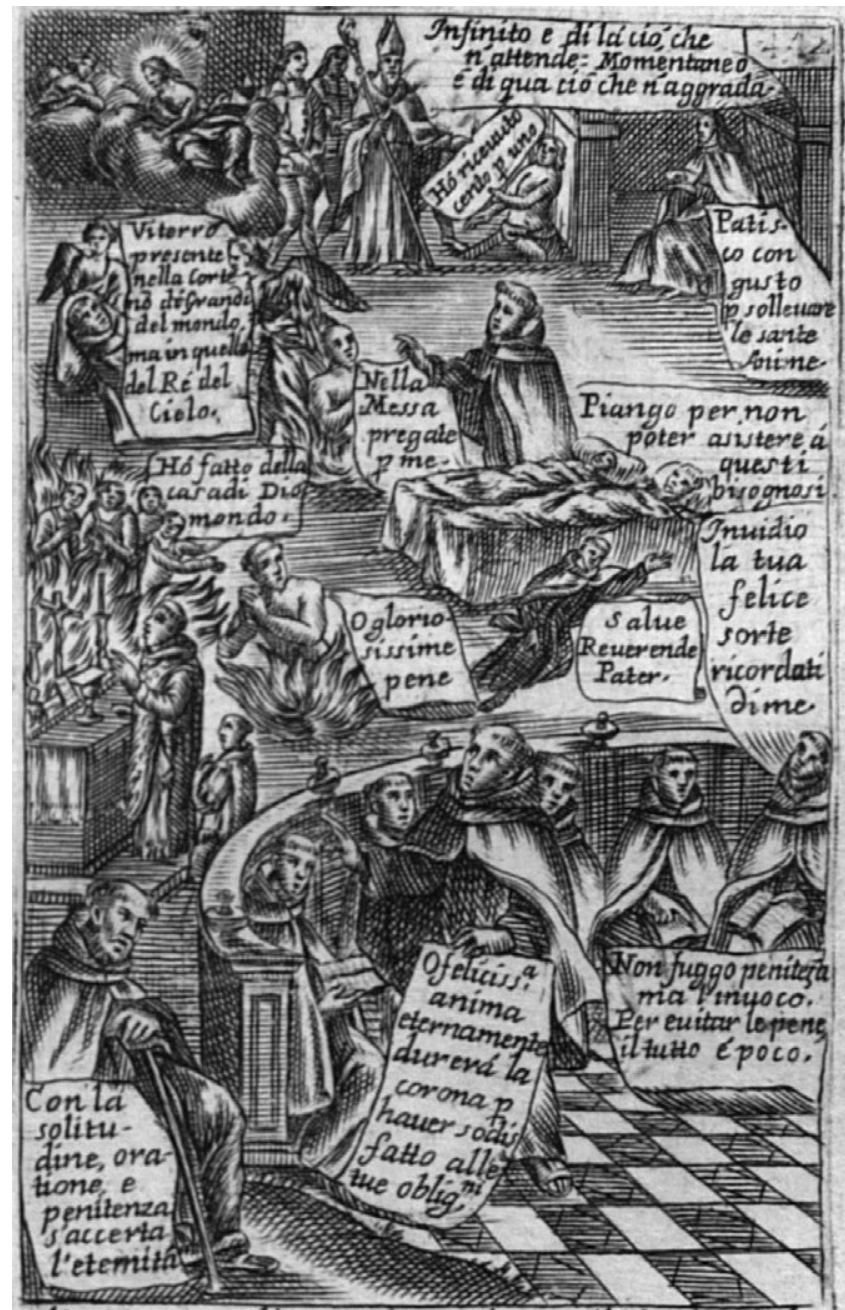

IV P.P. Tomaso di Giesí, Dias Sanches, Daulla fondatore de

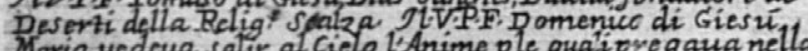
Maria, uedeua salir ficielo listime ple quati pregana nella

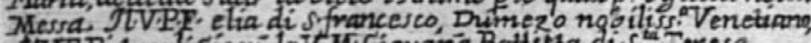

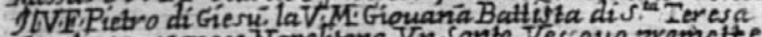

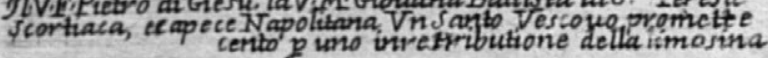

Francisco de la Cruz 1687. Disinganni. Per Viuere e Morir bene. Sopra le cinque Parole di S. Paolo apostolo. Commentate Per l'Angelico Dottore S. Tomaso e dichiarate Dal minimo Scalzo Carmelitano F. Francesco della Croce Con dottrine della sua Serafica Madre santa Teresa di Giesv, E con esempij della sua Religione. Prima in lingua Spagnola, e poi con aggiunta nell'Italiana, abbellite con diuerse Lamine, diuise in cinque Libri. Napoli: Giuseppe Roselli, 1687. Se trata de un volumen in folio que bajo la misma paginación integra las cinco palabras. La cuarta palabra está formada por 2 folios no numerados más las p. 411-562, y tiene la siguiente portada: Qvarta parola dell'apostolo S. Paolo. Credenda. Applicata al Purgatorio. E dedicata alle SS. anime del Purgatorio. Napoli: Giuseppe Roselli. A partir de un ejemplar de la Biblioteca de Catalunya [signatura: Toda 16-II-10], reproducimos esta estampa, que mide $125 \times 70 \mathrm{~mm}$ y se inscribe en el centro de la p. 543, con el texto editado a su alrededor. Pocos años después, ocupando el espacio de toda la página, la misma matriz fue reutilizada en dos ediciones napolitanas in octavo: Francisco de la Cruz 1691. Quarta parola dell'apostolo S. Paolo. Credenda. Applicata al Purgatorio: [529]. Napoli: Giuseppe Rosselli. Francisco de la Cruz 1711. Quarta parola dell'apostolo S. Paolo. Credenda. Applicata al Purgatorio: [530]. Napoli: Felice Mosca.
FIGURA 3

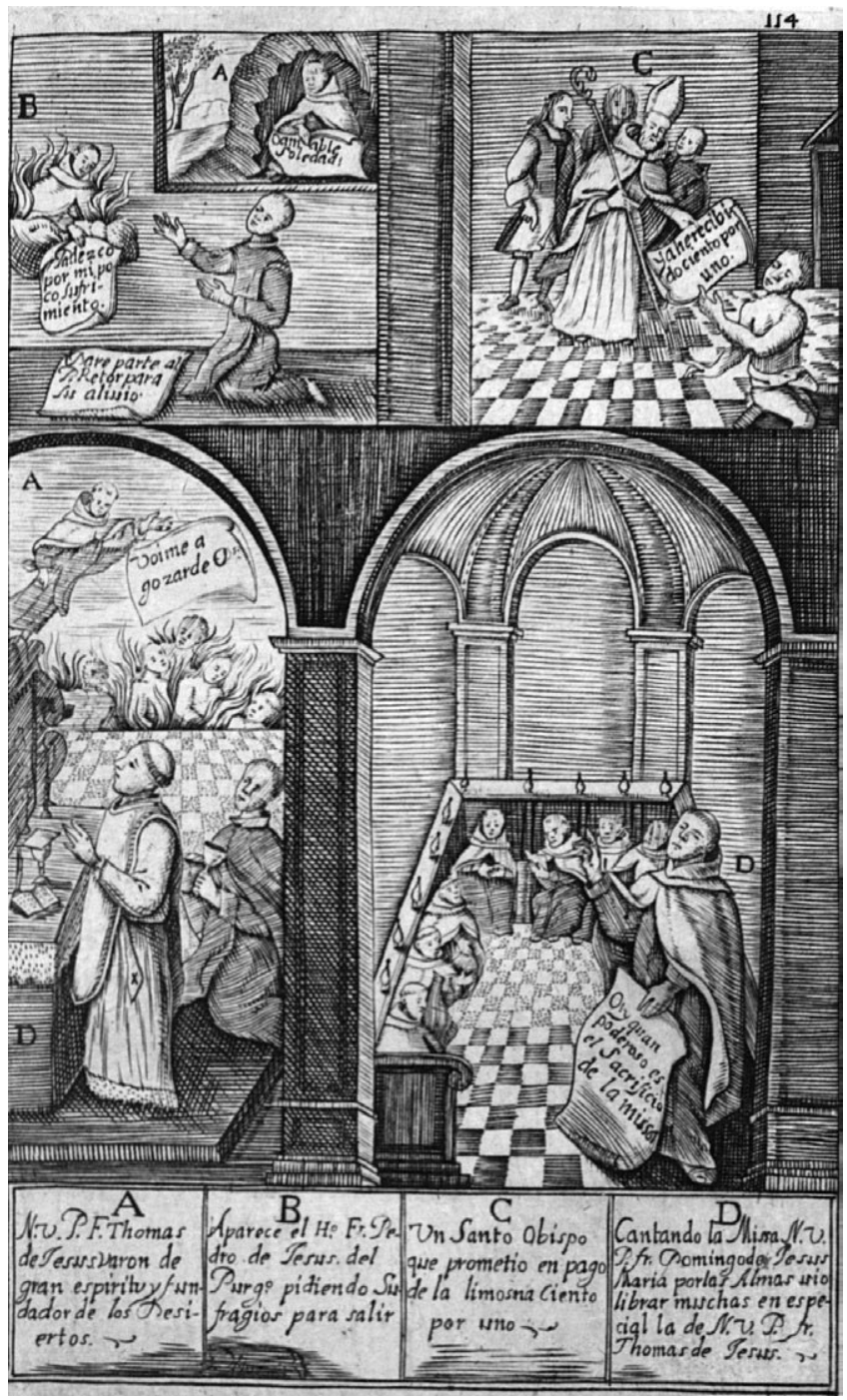

Francisco de la Cruz 1724. Cinco palabras del apostol san Pablo, Comentadas por el Angelico Doctor santo Thomas de Aquino, $Y$ declaradas por el menor Carmelita Descalço fray Francisco de la Cruz, Con doctrinas de su Madre Serafica santa Teresa de Jesus, y exemplos de su orden que dispiertan para vivir, y morir bien. Tomo segundo. Contiene dos palabras, Credenda, Speranda. Impresso en Napoles por Marco Antonio Ferro año 1680. Y reimpresso en Valencia por Antonio Balle año 1724. Valencia: Antonio Valle. Con unas dimensiones de $165 \times 105 \mathrm{~mm}$, esta estampa se localiza en un folio interpolado entre las p. 114 y 115 del volumen, que reproducimos a partir de un ejemplar de la Biblioteca de Catalunya [signatura: Res 1467-8º].

LAS VERSIONES ESCRITAS POR FRAY JUAN DE SAN JOSÉ Y SUS FUENTES

Volvemos ahora al análisis de las dos redacciones conservadas en los mss. 990 y 991 . Hemos indicado que el texto de la primera presenta una versión mucho más extensa y circunstanciada de los hechos, con numerosos comentarios eruditos y ejemplos morales o hagiográficos. Aparte de las referencias bíblicas y de otras fuentes como san Agustín, san Bernardo o santa Teresa de Jesús, el ms. 990 reitera, con bastante frecuencia, las autoridades del obispo de Osma Juan de Palafox y Mendoza (1600-1659), del cardenal César Baronio (1538-1607) 
y del Papa san Gregorio Magno († 640). A todas estas fuentes nos referiremos en el aparato de notas que acompaña a la edición del texto que figura al final de este artículo.

Fray Juan de San José aprovecha los Dialogi, de Gregorio Magno, en sus disquisiciones a propósito del martirio y en el ejemplo de la aparición de Pascasio, en proceso de purificación, caso especialmente elocuente para ilustrar hasta qué punto se debe mantener el honor y obediencia al superior. ${ }^{15} \mathrm{En}$ efecto, la pena que sufriría Pascasio por desacatar la autoridad del Papa Símaco sería equiparable a la de fray Pedro de Jesús por la escasa atención prestada a la reprensión de su prelado.

Por otra parte, los anales y el martirologio romano de César Baronio son aludidos y citados por el cronista del Carmelo en diversos pasajes referentes a los mártires de Alejandría. ${ }^{16}$

De esta manera se establece un paralelismo entre los tres carmelitas que murieron en Bellpuig y estos mártires de Alejandría, considerados como tales por el martirologio romano, precisamente, porque asistieron al prójimo durante la pestilencia, haciéndolo heroicamente y hasta la muerte. Dado que, en estos casos, el ms. 990 refiere la fuente y la cita fielmente en latín, hemos optado por colocar las referencias concretas en diversas notas a pie de página, que se incluyen en nuestra edición.

La obra de Juan de Palafox titulada Luz a los vivos y escarmiento en los muertos es reelaborada de manera distinta a las autoridades de san Gregorio Magno y de César Baronio. ${ }^{17}$ De manera más libre pero no menos intensa, fray Juan de San José adapta diversos pasajes del obispo de Osma referentes a las penas del Purgatorio, cuyos rigores son sufridos o incluso deseados por hombres y mujeres santos o venerables.

En la línea de muchos de los casos referidos por Juan de Palafox, el relato de fray Pedro de Jesús vendría a representar la figura del religioso totalmente entregado a Dios y al prójimo, hasta dar la vida, y que, sin embargo, debe sufrir las penas del Purgatorio por una falta leve cometida contra la regla y el prelado.

Todos los pasajes que parecen inspirarse en el obispo de Osma se localizan en los fragmentos [2] y [8] de nuestra edición del ms. 990. En ambos fragmentos se menciona explícitamente el nombre de Palafox. En el primero, además, se refiere el Purgatorio de san Severino, se asegura que santa Teresa rogaba a una de sus hijas que, llegado el momento, la sacase del Purgatorio, y se citan unas palabras de Luis de la Puente. Por otra parte, el fragmento octavo nos recuerda el caso de Taulerio. Compárense todos estos ejemplos con los respectivos pasajes del ms. 990 que editaremos más adelante:

15 Gregorio Magno 1978-1980. Dialogues. [I: Introduction, bibliographie et cartes par Adalbert de Vogüé]. [II: Livres I-III. Texte critique et notes par Adalbert de Vogüé. Traduction par Paul Antin]. [III: Livre IV. Texte critique et notes par Adalbert de Vogüé. Traduction par Paul Antin]. Paris: Cerf.

16 César Baronio 1589. Martyrologivm Romanvm. Ad novam kalendarii rationem, et ecclesiasticae historiae veritatem restitvtem. Gregorii XIII. Pont. Max. ivssv editvm accesservnt notationes atque Tractatio Martyrologio Romanos: avctore Caesare Baronio Sorano Antverpiae: Ex officina Christophori Plantini. César Baronio 1864. Annales ecclesiastici denuo excusi et ad nostra usque tempora perducti ab Augustino Theiner. Tomus tertius: 253-317. Parisiis / Bruxellis: BarriDucis / Ludovicus Guérin.

17 Palafox y Mendoza, Juan de 1661. Lvz a los vivos. Y escarmiento en los mvertos. Por el ilvstrissimo, y Reuerendissimo Señor Don luan de Palafox y Mendoza, Obispo de Osma, del Consejo del Rey N. Señor. Madrid: María de Quiñones.

\begin{tabular}{|c|c|}
\hline Ms. 990 & Juan de Palafox y Mendoza 1661 \\
\hline Cf. § [2] & 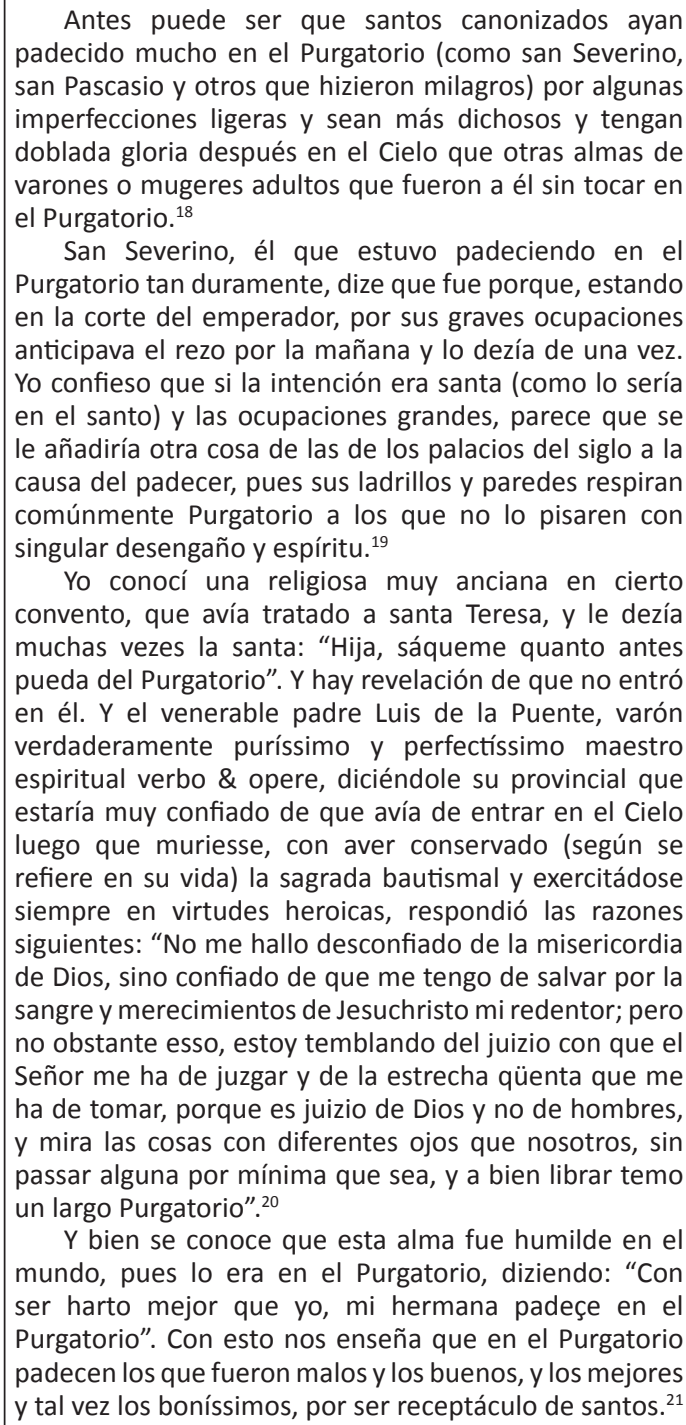 \\
\hline Cf. § [8] & $\begin{array}{l}\text { Quando murió el venerable maestro fray Juan } \\
\text { Taulero, una de las estrellas de la religión de santo } \\
\text { Domingo, espiritualíssimo varón, se apareció a } \\
\text { aquel santo labrador que Dios le dio por maestro. Y } \\
\text { preguntándole si padecía mucho, dixo que padecía tres } \\
\text { días de ausencia de Dios. }{ }^{22} \\
\text { Dos cosas deven advertirse aquí. La primera, que no } \\
\text { quiso Dios sacarle del Purgatorio hasta que por medio } \\
\text { de la religiosa pidiesse sufragios, que es lo mismo que } \\
\text { pedir perdón a su provincial, a quien ofendió, pues fue a } \\
\text { besar el azote o la correa desde la otra vida. Porque assí } \\
\text { se pagan en la otra vida las deudas del honor como las } \\
\text { de la hazienda. }{ }^{23}\end{array}$ \\
\hline
\end{tabular}

18 Ibídem: $\mathrm{s} / \mathrm{n}$, coincidiendo con el reverso de un folio cuya signatura es C, en la "Introdvccion".

19 Ibídem: 86, notas a las relaciones 45-47, § 159

20 Ibídem: 21 , notas a la relación $14, \S 53$.

21 Ibídem: 323, notas a la relación 209, §540.

22 Ibídem: 41 , notas a la relación $29, \S 103$.

23 Ibídem: 89, nota a la relación 47, § 165. 
Ponemos fin a este breve análisis de las fuentes que fray Juan de San José retoma en su dilatado discurso, con el fin de explicar por qué fray Pedro de Jesús tuvo que sufrir en el Purgatorio antes de acceder a la visión de Dios. A continuación pasaremos a sintetizar las conclusiones a las que hemos llegados a lo largo de este trabajo, para centrarnos después en la edición de las versiones de fray Juan de San José.

\section{CONCLUSIONES}

En las páginas precedentes hemos presentado un abanico diverso de fuentes textuales y gráficas que representan de diversos modos la aparición de fray Pedro de Jesús desde el Purgatorio. Se trata de uno de los tres carmelitas descalzos que en 1599 socorrieron a los apestados de Bellpuig. Si la crítica contemporánea ha mostrado cierto interés por estos episodios de la peste, el caso del difunto en vías de salvación ha pasado desapercibido, probablemente porque no guarda una relación tan estrecha con el contexto histórico en el que se enmarca, o quizás porque no aporta demasiadas certezas de base empírica para reconstruir la biografía de los carmelitas descalzos. Sin embargo, esta anécdota sobre la vida de ultratumba circuló desde el siglo XVII a través de diversas obras historiográficas sobre la descalcez, algunas de ellas impresas, como por ejemplo la cuarta de las las Cinco palabras del apóstol san Pablo, de Francisco de la Cruz, donde se insertan varios grabados que representan plásticamente los sucesos inmediatamente anteriores y posteriores a la muerte de fray Pedro. La notable difusión de la obra de Francisco de la Cruz, reeditada cinco veces en Nápoles, demuestra hasta qué punto el caso de fray Pedro fue asimilado a la historiografía carmelitana internacional.

En todas las fuentes que refieren este suceso predomina claramente el contenido historiográfico, pero puede observarse una diferencia de enfoque entre los textos e imágenes estampados y las reescrituras manuscritas de fray Juan de San José, que editaremos más adelante, ya que en estas últimas se abre una discusión de carácter teológico para explicar por qué merece sobrellevar las penas del Purgatorio una alma que ha entregado su vida por salvar a los apestados. Es cierto que las fuentes impresas se plantean estas mismas cuestiones, pero lo hacen de manera mucho más sintética, con un sesgo que se aproxima más a la exaltación devota que a la inquisición teológica.

\section{EDICIÓN SINÓPTICA DE PASAJES DE LOS MSS. 990 Y 991}

Antes de pasar a la transcripción del texto propiamente dicho, hemos establecido los criterios que regirán nuestra edición de las dos versiones escritas por fray Juan de San José. Advertimos que ya hemos seguido estos mismos criterios a la hora de transcribir textos como los de fray Francisco de Santa María, fray Francisco de la Cruz o Juan de Palafox. Hemos intentado mantener al máximo las soluciones gráficas de los testimonios originales, pero seguimos la ortografía actual en la acentuación, puntuación y el uso de mayúsculas y minúsculas.

También resolvemos amalgamas y separamos las palabras de acuerdo con la ortografía actual. Hemos transcrito en mayúscula "Cielo", "Purgatorio" y "Madre de Dios". Solamente hemos regularizado las grafías en las alternacias $u / v, i / j$ y $y / j$. La regularización de todos estos casos, $y$ también la distinción entre $I / / I \cdot I$, responde a la necesidad básica de evitar graves confusiones en la correspondencia entre grafías y fonemas: con esta finalidad hemos transcrito, por ejemplo, "illustre" en lugar de la lección del original "illustre". En cambio, no hemos regularizado las alternancias $i / y, b / v, m / n, c / s / z+e / i / y, s / z+a$, ni otras soluciones al margen de la ortografía actual como puede ser el uso o desuso de algunas consonantes dobles, algunos fenómenos vocálicos de contacto o cambio de timbre, algunos cultimos gráficos y algunos casos de composición léxica: "carydad", "increýble", "diezysiete", "dexava”, "triumfos", "satizfazer", "rezarsir", "espressado", "bolviesse", "successivo", "honrrar", "summissión", "Mattheo", "laesa”, "antiochenos", etc. Hemos utilizado también el apóstrofo para separar algunas contracciones usuales en diversas lenguas románicas: "d'ello", "d'él", etc. En cambio, para marcar un caso mucho más inusual, hemos recurrido al punto medio: "desde.l". Desarrollamos abreviaturas e iniciales, por ejemplo, "venerable hermano fray" en lugar de "V. Hermano Fr.".

Utilizamos el acento diacrítico cuando á se refiere a la tercera persona de singular del presente de indicativo del verbo haber. Hemos marcado en cursiva y entre comillas tanto las citas como las intervenciones de los personajes en estilo directo. Para los pasajes en latín, regularizamos las alternancias $u / v$ y $i / j$ de acuerdo con las soluciones fonéticas características del latín eclesiástico, y también del latín de la Edad Moderna. Hemos indicado con una barra los saltos de página o de folio, marcando en superíndice la numeración manuscrita que tomamos como referencia. Los fragmentos manuscritos espurios o indebidamente repetidos han sido marcados entre $\langle>$, mientras que añadimos entre [ ] el texto que no figura en los testimonios originales, como sucede por ejemplo en la numeración de los fragmentos paralelos de ambas versiones.

Algunas de las notas a pie de página, concretamente aquellas en las que el factor numérico va acompañado de un asterisco, constituyen referencias cruzadas que remiten tanto al texto del ms. $990 \mathrm{com}$ al del ms. 991. Aunque esto provoca algunos saltos en la numeración e incluso en el orden de las notas del texto del ms. 991, este procedimiento facilita una localización más detallada de pasajes paralelos entre ambas redacciones. Un vez terminada esta breve exposición preliminar, pasaremos a la edición propiamente dicha. 
[Biblioteca de la Universidad de Barcelona, ms. 990, p. 645ª-655a]

[Biblioteca de la Universidad de Barcelona, ms. 991, p. 182ª $-184^{\mathrm{b}}$, § 614-621]

[1] Capítulo XIX. Aparécese el hermano fray Pedro de Jesús diziendo estava en el Purgatorio, y pondéranse algunos reparos

A la misma hora que murió en Bellpuig, el hermano fray Pedro se apareció en Lérida al hermano Josef de Jesús María (de quien hizimos ya mensión en la fundación de aquel colegio, y haremos más cumplida de sus grandes virtudes el año 601, como allí ofrecimos) ${ }^{24^{*}}$ en esta forma: estándose en su celda, le vio entrar en ella y que, tomando agua bendita, hizo una profunda inclinación a una santa Verónica que allí estava. $\left.\right|^{645 b}$ Viendo esto, se turbó algo el hermano Josep y, animándole, el difunto dixo: "Yo soy el hermano fray Pedro de Jesús, que en esta hora acab[o] de espirar en Bellpuig. Pide perdón al padre retor de mi parte del poco sufrimiento y humildad con que llevé la reprehensión que tal día me hizo en secreto, porque por ella estoy en Purgatorio y no saldré hasta que en el sacrificio de la missa ruegue por mi". Con esto desapareció. Dio cuenta d'ello el hermano Joseph al prelado, el qual, en amaneciendo al otro día, le dixo missa y le mandó dezir otras. ${ }^{10^{*}} \mathrm{Y}$ no aviendo buelto más el difunto, no dudaron averse ido a gozar de Dios. Esto es lo que sucedió. Y por ser el caso tan raro, por no averse librado del Purgatorio después de un acto tan heroico como avía hecho el bendito hermano, me pareció ponerlo aparte para discurrir más de espacio sobre él.

[2] No se estraña el ver en Purgatorio a este siervo de Dios sabiendo que san Severino no se escapó d'él y que muchos santos antes de morir se tenían por contentos de yr allá y aún lo suponían. Nuestra santa madre solía dezir muchas vezes a una religiosa: "Hija, sáqueme presto del Purgatorio". El venerable padre Luis de la Puente, de quien se dize en su historia aver conservado la gracia bautismal, dixo: "Estoy temblando del ju[i]zio de Dios y de la estrecha cuenta, porque mira las cosas con diferentes ojos que nosotros, sin passar alguna por mínima que sea; y a bien librar temo un largo Purgatorio". | ${ }^{646 a}$ Más apretó aún este punto san Bernardo con estas notables palabras: "Juzguen y sientan otros lo que quisieren, que yo aún no he hallado penitente alguno que no le juzgue necessitado del fuego y llamas del Purgatorio; y en quanto a mí, me tendré por felicíssimo si el Purgatorio me estuviere purificando hasta el día del Juizio de toda escoria, de manera que pueda tener ánimo de aparecer limpio delante del juez". Y en conseqüencia d'esto, dixo el il-lustríssimo y venerable señor don Juan de Palafox: "En el Purgatorio padecen los que fueron malos y los buenos y los mejores y tal vez los boníssimos, por ser receptáculo de santos". Ni menos admira el verle padecer a nuestro hermano por cosa que parece tan leve, porque finalmente sine macula, sine ruga se ha de entrar en el Cielo. ${ }^{26}$

[3] Lo raro, pues, del caso consiste en aver entrado en Purgatorio después de una acción tan heroica y tan heroicamente executada y continuada hasta la muerte, y muerte con lágrimas por no tener más vidas que sacrificar. ¿Qué mas puede hazer un hombre? ¿Qué penitencia se puede igualar con este acto? Y si la caridad es la que cubre la multitud de los peccados y la que da los méritos a las obras, ¿cómo, siendo esta (según la sentencia del Salvador) la mayor que cabe en nuestra humanidad, pudo dexar culpas que purgar y no dar bastantes caudales para satizfazer una deuda tan ligera? ¡Cosa verdadera- $\left.\right|^{646 b}$ mente digna de admiración! ¿Qué más puede azer la caridad que dar todo lo que tiene? Y dando uno todo lo que tiene satisfaze todas las deudas. Por esso al que devía a su amo diez mil talentos no solo le mandava vender a él sino también su muger, hijos y todo quanto tenía. Pues si la caridad d'este siervo de Dios se adelantó vendiéndose o sacrificándose a sí y quanto tenía, hasta su misma vida, que es lo sumo y que todo lo comprehende, ¿cómo aún le ponen a la cárcel y le piden más? ${ }^{27^{*}}$

[4] Y si se responde que todo lo dicho bastó para perdonarlo todo en quanto a la culpa pero no en quanto a la pena, no se aquieta el ánimo, porque toda pena supone no ser entera la satizfación y a nadie se le puede pedir más entera quando ha hecho todo lo que puede y dado quanto tiene. $Y$ por esso hallamos que tres cosas perdonan todos los peccados a pena y culpa, esto es el bautismo, la professión religiosa y el martyrio: el bautismo, porque nos incorpora y consepulta con Christo; la professión, porque es muerte civil y un holocausto perfecto que por medio de los tres votos sacrifica a Dios el hombre y todos sus bienes temporales, internos y externos; y el martyrio, porque muriendo el hombre por Christo y derramando la sangre en su testimonio $\left.\right|^{647 a}$ equivale al bautismo. Y assí, dize santo Thomás que en el bautismo y en el martirio se haze universal absolución de toda culpa y pena, cumpliéndose en el martirio todos los sacramentos del bautismo en quanto a la liberación plena de pena y culpa. ¿Pues qué le falta para equivaler a todo esto a un acto de tan perfecto sacrificio en que un hombre con heroica fortaleza desprecia y vence los temores de la muerte y con estraño fervor de caridad se ofrece y entrega todo en Christo y por Christo a la muerte, sirviendo a los apestados y enfermos, de quienes dixo el mesmo Christo: "Infirmus fui, et visitastis me, quod uni ex his minimis fecisti, mihi fecisti"? ${ }^{28}$ Si la muerte padecida por la fe de Christo haze mártyr, ¿por qué no lo hará también padecida por la caridad de Christo? Más perfectamente nos une a Christo la caridad que la fe, assí porque la fe obra por la caridad como porque la caridad es la mayor y la reina de todas las virtudes. No le de en hora buena la caridad a este acto lo formalíssimo del martirio, que es ser testimonio de la fe cathólica, porque esso se lo da la misma fe, ¿̇pero por qué no le dará la sustancia, el valor y el mérito, pues aún en el mismo martyrio todo esto lo obra la fe por la misma caridad?
[1] Capítulo XXXXVII. Aparécese el hermano fray Pedro de Jesús diziendo estava en Purgatorio

614. A la misma hora que murió en Bellpuyg, el hermano fray Pedro de Jesús se apareció en Lérida al hermano Joseph (no de la Madre de Dios sino de Jesús María, porque este es su nombre), ${ }^{24^{*}}$ y se le apareció en esta forma: estándose en su celda, el hermano Joseph le vio entrar en casa y que, tomando agua bendita, hizo una profunda inclinación a una santa Verónica que allí estava. Viendo esto, se turbó algo y, animándole el difunto, dixo: "Yo soy el hermano fray Pedro de Jesús, que en esta hora acabo de expirar en Bellpuyg. Pide perdón al padre retor de mi parte del poco sufrimiento y humildad con que llevé la reprehensión que tal día me hizo en secreto, porque por ella estoy en Purgatorio y no saldré hasta que en el sacrificio de la missa ruegue por mi". Y dicho esto, desapareció. Dio cuenta d'esto el hermano Josef al prelado, el qual, en amaneciendo al otro día, le dixo missa y le mandó dezir otras. ${ }^{25^{*}} \mathrm{Y}$ no aviendo buelto más el difunto, no dudaron averse ido a gozar de Dios. Esto es lo que sucedió. Y por ser el caso bien raro y harto dotrinal, me pareció ponerlo aparte para examinarlo más de espacio, que no será inútil la detensión.

[3] 615. Lo que tenemos por raro en este caso solo es que estuviese detenido en Purgatorio después de aver dado la vida tan heroicamente por la caridad del próximo, entregándose voluntariamente a servir los apestados con tan grande fervor de caridad, que murió llorando por no tener otras muchas vidas para sacrificarlas todas a la misma caridad. Esto es lo que se admira y se tiene por raro, porque, no aviendo mayor caridad que dar la vida por el próximo, no parece se le puede pedir más a un hombre, porque no puede hazer más. Al que $\left.\right|^{182 b}$ da quanto tiene, ¿qué le pediremos más? Por esso, a aquel siervo que devía a su amo diez mil talentos, le mandó vender a él, a su muger, hijos y todo lo demás que tenía -como refiere san Mattheoy con esso se contentava el acreedor. Pues si la caridad de este fiel siervo y bendito hermano se adelantó vendiendo o sacrificando quanto tenía por medio de los tres votos solemnes de religión y después asimismo dando la vida en este obsequio de tanta caridad, que es lo summo y lo más que podía hazer y que lo comprehende todo, ¿cómo aún le ponen en la cárcel y le piden más ${ }^{27^{*}}$ 
Biblioteca de la Universidad de Barcelona, ms. 990, p. 645 $\left.{ }^{\mathrm{a}}-655^{\mathrm{a}}\right]$

[5] Dictamen fue este de aquel grande Dionisio, obispo de Alexandría, que tanto engrandece el martyrologio romano el día diezysiete de noviembre de doctíssimo y $\left.\right|^{647 b}$ santíssimo; el qual, hablando de aquella horrible peste que el año 263 de Christo afligió a Alexandría y oprimió a todo el orbe, y del fervor y grande caridad con que muchos servían a los enfermos y morían en el ministerio, llega a dezir que su sacrificio nada se diferenciava del martyrio. Pero oygamos de su boca y con sus palabras todo el caso, que es admirable, dexándolo en su latín para que con nuestra versión no pierda su propriedad y elegancia. Dízelo el santo en una carta que escrivió a Hieraces, obispo, y la refiere Eusebio en el libro 7 de su Historia (capítulo 17), de donde trasladó Baronio los fragmentos que pone al año sobredicho, y de quien nosotros trasladaremos lo siguiente. Refiriendo el estrago de la peste, dize: "Ettenim jam lamentationum plena sunt omnia, jam lugent omnes, jam moerores, jam quaerelae universam urbem propter multitudinem cum illorum qui modo mortui sunt, tum horum qui quotidie moriuntur, occupant. Nam sicut de primogenitis Egiptiorum scriptum est; sic et nunc ingens clamor editur: Non enim est domus in qua non sit mortuus ... Cum pestis ista subito grassari coepit; res plane illis ad terrendum omni metu formidolosior, ad excruciandum quavis calamitate miserior acerbiorque". ${ }^{29}$ Dize esto último respeto de los gentiles. Bolviendo a los christianos, añade: "Verum nobis non ejus generis / ${ }^{648 a}$ putabatur; sed a Deo tum ad fidem nostram exercendam, tum ad tolerantiam animi probandam, [...] coelitus inflictam". ${ }^{30}$ Passando a descrivir el fervor de los fieles en obsequio de los enfermos, prossigue assí: "Quamplurimi e fratribus nostris adeo immenso quodam charitatis et fraternae benevolentiae ardore erant inflammati ut minime suae parcentes vitae sed ipsi firme inter se adhaerescentes eos qui morbo opprimebantur nulla sui cura aut cautione adhibita sedulo inviserent illis inservirent assidue, pro viribus ob Christi amorem curarent, una cum illis decederent e vita lubentissime aliorum contagione infecti, etiam morbum a proximis quodammodo ad se attraherent, suaque sponte aliorum moerores benevole mitigarent. Multi item dum aliis aegrotantibus curam adhibent, illisque vires restituunt ipsi aliorum mortem in se derivantes vitam amittunt et verbum illud quod vulgo semper dicitur quodque verae benevolentiae solum videtur convenire nimirum ut singuli pro amicis abeant e vita, seque eorum causa (ut ita dicam) rejectamemtum efficiant; reipsa expleverunt". ${ }^{11}$ Grande fue esta calamidad en los enfermos y mayor la caridad en los ministros, pero hasta aora no excede lo uno ni lo otro a lo que queda dicho de Bellpuig sino en el ser pueblo mayor Alexandría; antes le quadran tanto como si de hecho $\left.\right|^{648 b}$ se huviessen escrito de lo que passó en nuestra peste, como también se reconoce muy propriamente en lo que añade y concluye, diziendo: "Ex fratribus igitur, qui virtute facile erant praestantissimi, ad hunc modum mortem oppetiverunt; quorum nonnuli erant praesbiteri, alii diaconi, quidem a populo virtutis ergo multum laudati adeo ut istud mortis genus, quod propter incredibilem pietatem, robustam fidem suscipiebatur, nihil a martirii splendore abesse videretur. Quin etiam sanctorum corpora manibus erectis supinisque excipere, gremio suo reponere, occludere oculos, ora obturare, gestare humeris cadavera, decenter ornare, illis adhaerescere, amice complecti, lavare accurate, et linteo funebri involvere, non gravati sunt: ipsique qui supererant, paulo post similia officia in se collecta propterea adepti quod eandem mortis viam instarent, quam qui praeiverant, institissent". ${ }^{32}$ De suerte que sintió aquí el santo que aquel género de muerte, por la increýble piedad y robusta fe con que la abraçavan aquellos santos y fervorosos ministros, nada se venía a diferenciar de los esplendores del martyrio. $Y$ ha tenido tanta aucthoridad su dicho que, aprobándolo la Iglesia, lo puso en su martirologio, dando lugar a aquellos santos ministros entre las relaciones $\left.\right|^{649 a}$ de sus gloriosos mártyres el día 28 de febrero, con estas palabras: "Ibidem (esto es Alexandría) commemoratio sanctorum praesbiterorum, diaconorum et aliorum plurimorum qui temporem Valeriani impaeratoris, cum pestis saevissima grassaretur, morbo laborantibus ministrantes, libentissime mortem oppetiere; quos velut martyres religiosa piorum fides venerari consuevit". ${ }^{33 *}$ Con estas calificaciones, mucho tienen de mártyres (ya que no lo tengan todo) semejantes ministros. Y pues apenas se hallará cláusula en las referidas de san Dionisio que no se verifique de nuestros tres ministros en la peste de Bellpuig (y con especialidad en el venerable hermano fray Pedro, de quien aora hablamos), no se le puede negar mucha parte d'esta gloria, pues tan uniformemente imitó a los de Alexandría. Pues si murió con gajes de mártyr, ¿cómo es detenido en el Purgatorio? ¿Cómo no bastó para volar derecho al Cielo una caridad tan fervorosa, una piedad tan increíble y una fe tan robusta como la que nos refiere san Dionisio?

[6] Cierto es que el martyrio, mirando la fe como a fin, es acto imperado de la caridad y elícito de la fortaleza, y creería yo que no es inferior la caridad que concurre a sacrificarse un hombre a la muerte en servicio de los apestados que la que concurre al martyrio, pues ambas dan la vida por Christo, diziendo su magestad hablando de los enfermos: "Quod uni ex his minimis /649b fecistis, mihi fecistis", ${ }^{4}$ aunque la fortaleza para el martyrio en muchos casos deve ser mayor por la especial dificultad de sufrir la acerbidad de grandes tormentos (si bien en otros casos no necessitará de tanta por no ser tan crueles las penas, como en los que solamente fueron de presto degollados y otras maneras de muertes de verdaderos mártyres que no excedieron las penalidades y los dolores de los que mueren de la peste sirviendo a los apestados). Con que pareçe no aver repugnancia en que ambos obsequios sean iguales en la caridad y fortaleza. De donde se puede inferir la igualdad también en el mérito, porque si para el del martyrio basta, en sentencia de san Gregorio, la preparación del ánimo o dezeo fervoroso, iquánto más bastará una equivalente execución de la muerte! Dízelo assí san Gregorio en el cap. 26 del libro tercero de sus Diálogos: "Duo sunt martyrii genera: unum in occulto, alterum in publico. Nam et si persecutio desit exterius, martyrii meritum
[Biblioteca de la Universidad de Barcelona, ms. 991, p. $\left.182^{\mathrm{a}}-184^{\mathrm{b}}, \S 614-621\right]$

[5] Y si el morir sirviendo heroicamente a los apestados le compara y asemeja al martirio como de los que murieron d'esta manera en la peste de Alexandria, a los quales no fueron inferiores estos tres que murieron en Bellpuyg (lo confirma el martyrologio romano el día 28 de febrero), ${ }^{33^{*}}$ y en el martyrio se haze universal absolución de toda culpa y pena, como enseña santo Thomás, ¿cómo después de en martyrio de carydad tan il.lustre no le hallamos a nuestro hermano absuelto de la pena del Purgatorio? 
Biblioteca de la Universidad de Barcelona, ms. 990, p. 645a $\left.-655^{\mathrm{a}}\right]$

[Biblioteca de la Universidad de Barcelona, ms. 991, p. $\left.182^{\mathrm{a}}-184^{\mathrm{b}}, \S 614-621\right]$

in occulto est, cum virtus ad passionem prompta flagrat in animo". ${ }^{35} \mathrm{Y}$ lo confirma el santo con las palabras que dixo Christo a Santiago y a san Juan ("Calicem quidem meum bibetis"), ${ }^{36}$ que en san Juan se verifica sin aver padecido martirio, de lo qual infiere que muchos grandes siervos de Dios, de quien antes avía tratado, eran en quanto al mérito mártyres, diziendo d’ellos: “Qui occulte antiqui hostis insidias / ${ }^{650 a}$ tolerantes, suosque in hoc mundo adversarios diligentes, cunctis carnalibus desideriis resistentes, per hoc quod se omnipotenti Deo in corde mactaverunt, etiam pacis tempore martyres fuerunt". ${ }^{37}$ No siendo, pues, inferior a todo esto el sacrificarse y morir sirviendo a los contagiosos, tampoco lo deve ser el mérito. Todo esto favorece y píamente inclina a sentir que el bendito hermano fray Pedro, después de tan heroica muerte, avía de entrar sin dilación en su gloria, y estraña y admira verlo detenido en Purgatorio. Sin embargo, lo vemos en él, sin poder caber en Dios la más mínima injusticia. Lo que en abono de la divinal rectitud en este caso podemos rastrear lo dirá el capítulo siguiente, para que este no sea molesto.

[7] Capítulo XX. Esplícase la aparición y cessan todos los reparos

Dexando aparte los secretos juizios de Dios y lo delgado de su divina justicia, que ni podemos alcançar ni devemos con curiosidad escudriñar, diremos llanamente (supuesta la verdad de la referida aparición) lo que en su abono y justificación alcançaremos, satisfaçiendo juntamente los reparos propuestos en el antecedente capítulo. ${ }^{650 \mathrm{~b}}$ Por dos cosas solamente, según dotrina de san Agustín, se padece en Purgatorio: la una son los pecados veniales; y la otra, alguna obligación de satizfación no cumplida o en todo o en parte..$^{38^{*}} Y$ devemos suponer que el venerable hermano no fue detenido en Purgatorio por la primera, porque por la grandeza de la obra que executó en su muerte le perdonó la divina Misericordia todos sus pecados a pena y culpa, como se infiere de sus mismas palabras, pues dixo que pidiesse perdón al prelado de su parte por el poco sufrimiento que tuvo en la corrección que le hizo, y que por esso estava en Purgatorio. El pedir perdón es satizfazer. Y no aviendo espressado otra causa de su Purgatorio, fue dezir que por sola ella estava allí. Luego no por peccados veniales, que es la primera cosa o causa de estar en Purgatorio, sino por la satizfazión no cumplida que devía al prelado, que es la segunda. Y en esta suposición de que esta satizfación solamente le detenía, se sigue bien que, de todos los demás pecados que tuviesse, assí veniales como mortales ya confessados, entró libre y absuelto en su Purgatorio.

[8] Y que esta sea rigurosa satizfación y devida de justicia también se infiere de sus mismas palabras ("del poco sufrimiento -dize-y humildad con que llevé la corrección que me hizo en secreto"), pues poco sufrimiento y humildad en | ${ }^{651 a}<\mathrm{en}>$ Ilevar una corrección -y secretahuele a que quiçá respondiera alguna palabrica menos reverente al prelado para escusarse. Era muy fervoroso este santo hermano, como se ve en lo que obró en Bellpuig. Y llevado de su natural ardiente (porque sin duda le devía parecer a él que no tenía culpa o que no tanta como la corrección suponía), devió de tener algún poquito más de aliento de lo que devía en escusarse y defenderse, que en varones harto espirituales suceden fácilmente semejantes deslizes de la lengua, porque nunca ofender con ella es de muy perfectos, según la sentencia del apóstol Santiago..$^{39}$ Pero fue finalmente irreverencia al prelado, y por la irreverencia se ofende el honor, y este pide satizfación, siendo la más adequada en este género el pedir perdón. ¿Mas cómo, siendo esta irreverencia o lesión del honor tan leve y en secreto, no pudo tener dispensación? ¿Cómo fue juzgada por tan indispensable en el divino tribunal que mandó bolver desde.l Purgatorio a satizfazerla? No es fácil el tanteo en semejantes materias, y de buena gana callara yo para oýr a los que saben más, pero, ya que no podemos escusar el dar salida, dirá nuestra cortedad lo que alcançare. Y para dar principio, diré que parece este caso execución de aquel precepto de Christo quando, en el quinto de san Matheo, dixo: "Si llegares a querer ofreçer tus dones $\left.\right|^{651 \mathrm{~b}}$ al altar y allí te acordares que tu hermano tiene alguna quexa de ti, dexa allí tu ofrenda y ve primero a reconciliarte con él". $40^{*}$ Esto mandó el que es juez de vivos y muertos, y creo que a muertos y vivos quiso comprehender. Llegava, pues, este bendito hermano a la hora de su muerte con las manos llenas de ricos dones y preciosas obras a ofrecerlas al altar de los divinos ojos y que merecían ser acceptadas y bien recibidas, pero acordosse en espirando (porque entonces nada se olvida) de la irreverencia que avía tenido a su prelado y, diziéndole que no entraría al altar que no se reconciliasse primero con él, juntamente le manda yr al mismo punto a pedirle perdón. Y se puede creer que el Purgatorio que en el ínterim padeció solo fue privación de ver a Dios, no de llamas ni otras penas, como del venerable Taulerio y otras almas se lee. Assí que no le abrieron las puertas del Cielo, hasta que satizfizo. Dixo el venerable Palafox que en el Purgatorio assí se pagan las deudas del honor como las de la hazienda, de donde infiero que assí como <en> el bautizmo (que es la puerta de la Iglesia y de la gracia) no se deve dar a los adultos (como enseña santo Thomás) sin que primero ayan satizfecho o restituydo sus deudas, assí tampoco no se da la entrada del Cielo sin que preceda la satizfación. Sin ella no se abren al adulto | ${ }^{652 a}$ las puertas de la gracia en el bautismo. ${ }^{41^{*}}$ No se abran tampoco las de la Gloria sin ella al difunto del Purgatorio, porque la justicia pareçe ser la puerta de la Gloria, como denota David en el psalmo 117: "Aperite mihi portas justitiae; ingressus in eas confitebor Domino: haec porta Domini justi intrabunt in eam". ${ }^{42}$ Assí que la justicia es la puerta del Señor
[7] 616. Suponiendo y venerando los profundos juizios de Dios, y adorándolos y confessándolos todos por justíssimos, santos y rectos, lo que en abono y justificación del presente puede rastrear y opinar nuestra cortedad, sujetándolo humilmente a toda corrección y mayor intel-ligencia, es lo siguiente: que, supuesto todo el caso como se ha referido y suponiendo lo que enseña san Agustín que por dos cosas se pacede en el Purgatorio (que son o pecados veniales o alguna obligación de satizfación no cumplida en todo o en parte), ${ }^{38^{*}}$ la causa que le detenía al hermano en Purgatorio era la obligación de satisfazer a su prelado la irreverencia que le tuvo con el poco sufrimiento y humildad con que tomó su corrección, como claramente lo significan sus mismas palabras con que murió el bendito hermano, con la deuda de resarzir el honor y reverencia del prelado en que avía faltado.

[8] Suppongamos también lo que dixo el venerable señor don Juan de Palafox que en el Purgatorio así se pagan las deudas del honor como las de la hazienda, y lo que asienta santo Thomás que a los adultos no se deve dar el bautismo sin que primero ayen satizfecho o restituydo las deudas que $\left.\right|^{183 a}$ tuvi[er]en. ${ }^{41^{*}}$

617. Supuesto todo esto, dezimos que, por ser la restitución del honor acto de justicia commutativa, después de aver hecho el bendito hermano todo lo que hizo y padeció sirviendo los apestados hasta morir en la demanda tan gloriosamente, se le quedó en pie la dicha obligación de restituir al prelado su devido honor sin que todos sus trabajos y grandes méritos le pudiessen librar d'ella. La razón es clara, porque alta justicia mira igualdad de cosa a cosa y la restitución que debe haber (siendo possible) en el mismo género de bienes, por donde la restitución del honor se debe hazer con actos que honrren la persona lesa y ordenados a esse fin. De donde parece que, por averse el bendito hermano ofrecido a servir los apestados y averlo hecho con tanto fervor hasta dar la vida, pudo grandemente satisfazer por todas sus culpas, pero no esta deuda de rezarsir el debido honor a su prelado, porque todo aquello (aunque tan grande y excel-lente) no era medio proporcionado ni de este género, ni se encaminava al prelado ni se hazía en su obsequio y reverencia. Y así es muy conforme a justicia que, después de pagadas tan abundantemente todas las demás deudas, le quedasse sola esta por satisfazer, por quanto 
en la qual entrarán los justos. Y como el verdadero y perfectamente justo sea el que tiene aquellas obras no eran d'este género ni se cumplidas todas las obligaciones de justicia según aquella sentencia del Salvador ("Oportet nos implere omnem justitiam"), ${ }^{43^{*}}$ de aquí parece no poder entrar en la Gloria el que tiene alguna obligación de justicia contrahida, hasta que la aya cumplido y satizfecho.Y con especialidad si fuere de restitución del honor o fama del próximo, por ser de justicia tan rigurosa. Y assí pr leemos de muchas almas que bolvieron del Purgatorio a hazer semejantes satizfaciones, siendo todo esto muy conforme y conseqüente a aquella sentencia de san Agustín: "No se perdona el pecado, sino que se restituya lo quitado". ${ }^{44}$ Algo avía quitado al respeto y reverencia que un súbdito deve a su prelado, que está en lugar de Dios, aquel poco sufrimiento de la reprehensión que devía resarzir nuestro hermano en vida pidiendo con mucha humildad perdón a su prelado. No lo hizo, o sea por aver hecho poco caso d'ello o por olvido o inadvertencia, con que $\left.\right|^{652 b}<$ con que> murió con la deuda y, al tomar las cuentas, abandónanle todo lo demás, no se passaron essa partida, porque por ella faltava al cumplimento de toda justicia, con que no podía entrar por aquellas dichosas puertas por donde solo entran los enteramente justos. No queremos dezir con esto que no pueda finalmente entrar en el Cielo el que no huviesse algo restituído, porque, aunque es grande esta obligación, solo es necessaria para la salud: necessitate praecepti, como dizen los theólogos. Con que el que muere con deudas con dezeo de que sean restituídas y bien confessado, llega al Purgatorio. Aunque sus herederos pequen después no pagando sus deudas, algún día entrará en el Cielo, quando la divina justicia se diere por satizfecha de sus penas. Lo que queremos dezir es que semejante obligación, quando se pudo restituyr y no se hizo, es una tranca tan fuerte que no dexa abrir las puertas del Cielo sino con la efectiva restitución o con mucho Purgatorio. Y por esso deve dispensar la divina piedad y misericordia en tantas ánimas (como leemos) a que buelvan a avisar y solicitar la restitución o satizfación de sus deudas, para que no sean tanto tiempo detenidas. Una d'estas fue la de nuestro hermano y, aunque fue poca su detensión, todavía no se acaba de entender cómo obras y muerte tan satizfactorias (pues, $\left.\right|^{653 a}$ siendo obsequio de los enfermos, pertenecen a la limosna, que es una de las tres obras satizfactorias), aviendo sido tan excelentes y heroicas, no bastaron para remitir esta pequeña obligación. Y si, como ya se ha dicho, bastaron para absolverle de todas las demás penas y obligaciones que tuviesse (como de hecho sucedió, pues por sola esta le detenían), ¿̇cómo no bastaron también para ella, siendo, como parece, tan leve y de tan poca malicia? Difficultosa parece la duda (y es la principal d'este caso), pero no lo será tanto si se atiende a la naturaleza de la justicia commutativa, cuyo acto es la restitución, porque esta justicia mira como a su proprio ojeto el medio de la cosa según proporción arismética, de cosa a cosa, de quantidad a quantidad, de número a número (como si quitaste diez reales, has de volver diez reales; si una pieça de paño, has de restituyr la misma), porque por esta justizia se reduzen las partes a igualdad real y quantitativa, no de proporción o proporcionalidad como haze la distributiva. Con que es preciso que, en virtud d'ella, se buelva y restituya a la parte laesa aquello mismo (en quanto sea possible) que la otra parte le avía quitado, de donde se sigue que la satizfación ha de ser con el mismo género de bienes siempre que no fuere impossible. De aquí, pues, consta que, por averse este bendito hermano ofrecido $\left.\right|^{653 b}$ a servir los enfermos y averlo hecho con tanto fervor, exemplo y trabajo hasta dar la vida llorando por no tener otras muchas que ofrecer, pudo grandemente satizfazer por todos sus pecados veniales y otras penas que deviesse, pero no por esta de satizfazer el honor a su prelado, porque ni eran medio proporcionado para ello ni se encaminavan al prelado ni se hazían en su obsequio o reverencia. Y assí es muy conforme a razón que después de pagadas (aunque sea superabundantemente) todas las demás deudas, le quedasse sola esta por satizfazer, por quanto sus obras (aunque tan relevantes) ni eran d'este género ni se encaminaron a este fin. $Y$ por aquí parece queda allanada la dificultad y desvanecidos todos los reparos. Allégase a lo dicho que no solo fue preciso este caso para el perfecto cumplimiento de la justicia (como se ha dicho), sino muy conveniente para mostrarnos Dios el summo respeto y reverencia que quiere tengamos a los prelados, y la humildad y summissión con que devemos llevar sus correcciones. "Nolite tangere Christos meos", 45 dixo de los prelados como quien dize aquí no ay que tocar, porque son las niñas de mis ojos. Obediencia quiero y no sacrificios..$^{46^{*}}$ Aunque estos sean los más costosos, no han de bastar para dispensar en esta parte. La más mínima deuda he de executar muy exacto, aún en los muy santos y perfectos. Refiere san Gregorio en sus Diálogos |654a que Paschasio, diácono de la santa Iglesia de Roma, varón de grandes virtudes y de continuas limoznas, tan honrrador y favorecedor de los pobres como despreciador de sí mismo, y de tan maravillosa santidad que llegó a hazer milagros con solo el contacto de su dalmática quando después de muerto estava tendida sobre su féretro, después de mucho tiempo apareció a Germano, obispo de Capua, penando en Purgatorio. ${ }^{47^{*}}$ La causa fue porque, aviéndose de hazer elección de summo pontífice, concurrían dos sujetos, que eran Sýmmacho y Laurencio. Paschasio se inclinó tanto a Laurencio que en todas maneras le prefería a Sýmmacho, y quería fuesse summo pontífice. Y aunque no salió con ello, porque todos los obispos eligieron a Sýmmacho, no obstante esso persistió toda su vida en amar, honrrar y preferir a Laurencio. Y por esto dixo él mismo que estava en Purgatorio. ¿Pues qué falta huvo aquí si él entendía que Laurencio era el más digno? Assí parece lo significa san Gregorio, diziendo que no creyó fuesse culpa: "Neque ipsi sine ultione laxaretur culpa, quam nec esse culpam credidit, et idcirco hanc fletibus non extinxit" ${ }^{48}$ Sin embargo, después de la elección de Sýmmacho, devía deponer de su dictamen viendo el común de todos los demás y, no reconociéndolo por su verdadero prelado, convertir en su estimación y reverencia todas aquellas honrras que conservó siempre a Laurencio y que no dexavan de redundar en $\left.\right|^{654 b}$ algún encaminaron a este fin. $Y$ así vemos que la satizfación que le mandaron hazer fue el pedir perdón al prelado, que es el acto más proporcionado en este género, porque con la sujeción de perdirle perdón derechamente rezarzía la irreverencia.

618. También parece razón harto congruente de que por las obras de supererogación (aunque sean grandes) no se satisfaze, ni quitan las obligaciones de justicia, mayormente no ordenándose a ello. Y como todo lo que hizo y padeció en Bellpuyg fue de supererogación y la deuda de la reverencia al prelado era de justicia (porque las leyes de nuestra religión, que avía professado el hermano y devía de justicia guardar, mandan esto con tanto rigor como explican sus palabras, que son estas: "Et quaelibet alia irreverentiae culpa etiam si levis appareat nullatenus impunita remaneat; ne honor et reverentia praelatis debita, non sine magno regularis disciplinae detrimento contemnatur"), ${ }^{49^{*}}$ falló en esta obligación de justicia, aunque levemente, $\left.\right|^{183 b}$ el bendito hermano; y por esto no se la perdonan por tantos y tan grandes obras de supererogación. Y parece que su detensión en el Purgatorio y hazerle bolver a pedir perdón no fue otra cosa que hazerle cumplir esta ley, especialmente aquellas palabras d'ella: "Nullatenus impunita remaneat". No se la avía castigado el prelado ni él la avía satisfecho, o por no aver echo caso d'ello pareciéndole cosa muy leve, o sea por inadvertencia o olvido. ¿Pues cómo avía de entrar en el Cielo no aviendo cumplido esta justicia? "Oportet nos implere omnem justitiam", ${ }^{43^{*}}$ dixo Christo a San Juan; y yo no dudo se entiendan también de todos los que ayan de entrar en el Cielo.

619. También parece este caso execución de aquella regla que nos dio Christo en el quinto de san Matheo, diziendo: "Si llegares a ofrecer los dones al altar y allí te acordares que tu hermano tiene alguna quexa de ti, dexa allí tu ofrenda y ve primero a reconciliarte con él". 40* $^{*}$ Esto mandó el que es juez de vivos y muertos, y yo creo que a muertos y vivos quiso comprehender. Llegava, pues, nuestro bendito hermano a la hora de su muerte con las manos llenas de ricos dones y preciosas obras a ofrecerlas al altar de los divinos ojos, pero acordose o acordáronle en espera d'él (porque entonces todo se acuerda y nada se olvida) de la irreverencia del prelado, diziéndole Dios que no entraría al altar que no se reconciliasse primero con él. ¿Por qué? Porque "obedientiam volo et non sacrificium". ${ }^{4 *} \mathrm{Y}$ con esto le mandó benigníssimamente que fuesse luego a pedirle perdón.

620. En tanto estima Dios la obediencia, reverencia y honor de los prelados, que en su comparación no haze caso de los sacrificios. Por esso dixo a nuestra santa madre que más estimava su obediencia que todas las penitencias (aunque eran tan grandes) de la venerable hermitaña Cathalina de Cardona; y se indignó tanto contra Saúl sin atender a su sacrificio porque no aguardó a Samuel hasta la hora que él le avía mandado, que luego le intimó la privación de su reyno y corona. Y más al intento de nuestro caso, refiere san Gregonio en el 
[Biblioteca de la Universidad de Barcelona, ms. 991, p. $\left.182^{\mathrm{a}}-184^{\mathrm{b}}, \S 614-621\right]$

menos crédito de Sýmmacho. Pues si ay algún defecto de estimación y reverencia al prelado, 4 de sus Diálogos que Paschasio, diácono de aunque sea un santo, lo ha de pagar en Purgatorio. ¿Y tantas limosnas? ¿No apaga la limosna la santa Iglesia de Roma, aviendo sido varón los pecados como el agua el fuego? ¿Tanta santidad, milagros y virtudes como concurrían santíssimo, grande limosnero, y que hizo mien Paschasio nada aprovecharon para esto? No; porque no lo satizfizo ni enmendó en vida, lagros, se apareció después de mucho tiempo púrguelo después de muerto en Purgatorio. ¿Qué ay más que admirar en nuestro hermano? Y a Germano, obispo de Capua, diziendo estava más si se pondera que, aunque en otra persona fuera su defecto más leve, más en un carmelita en Purgatorio y que la causa era porque, condescalço que professa una regla y leyes de tanta perfección, en que se hila tan delgado y se curriendo para la elección de summo pontífice repara tanto en qualquier falta, y en especial en esta materia, que con rigor promulgan sus Sýmmaco y Laurencio, se inclinó tanto | ${ }^{184 a}$ a leyes estas palabras: "Et quaelibet alia irreverentiae culpa, etiam si levis appareat, nullatenus Laurencio que en todas maneras le prefería a impunita remaneat: ne honor et reverentia praelatis debita (non sine magno regularis disciplina Sýmmaco, queriendo fuesse summo pontífice, detrimento) contemnatur". ${ }^{49^{*}}$ Sin duda, tiene más cuerpo y, en los ojos de Dios, mucho de cargo; y porque, aviendo elegido los obispos a Sýmultra que, mandando la ley que "nullatenus impunita remaneat", no hizo Dios más que hazerle cumplir esta ley por avérsela dissimulado en vida el prelado, según parece.

[9] Conque ninguna quexa puede quedar de la justicia, ni menos de la piedad y misericordia, pues aquella fue rectíssima y cumplimento de la misma ley que el reo avía professado. Y esta resplandeció maravillosamente en $\left.\right|^{655 a}$ este caso, dispensando en él dos singulares privilegios, porque privilegio grande fue el permitirle bolver a pedir perdón pudiéndole dexar que lo pagasse allá con más largo Purgatorio; y otro fue el que bolviesse no después de horas, días, meses o años (como vemos suceder en otros), sino al mismo instante que espiró en Bellpuig apareció en Lérida pidiendo el perdón. En que se descubren los grandes méritos d'este venerable hermano, pues mereciéronle abreviasse Dios quanto le fue possible el Purgatorio. Concluyamos notando que no solo pidió perdón al prelado (que parece avía de bastar), sino que también rogasse por él en la missa, que también parece pertenecer a la satizfación, pues por aguardar esso alargó el Purgatorio hasta el amaneçer del día siguiente. Yo diría que el pedir perdón fue precisamente por la irreverencia, y la oración en la missa que tuvo tracto successivo y duró algún rato fue por el descuydo, olvido o inadvertencia continuada hasta la muerte de no averle pedido el perdón (como devía) antes de morir. Finalmente cumplido todo esto, bolaría dichoso a celebrar en el Cielo con sus compañeros la gloria de sus triumfos, que si los antiochenos celebraron con annua festividad a santo Thomás monje porque por su oración hizo cessar la peste en su ciudad, estos la hizieron cessar en Bellpuig no solo con sus oraciones, sino también con sus muertes, que celebrarían mejor los del Cielo que los de la tierra. ${ }^{50^{*}}$ en viendo la elección de Sýmmaco, devía de- maco, persistió toda su vida en amar, honrrar y preferir a Laurencio..$^{47^{*}} \mathrm{Y}$ por esto dixo que estava en Purgatorio. ¿Pues qué falta cometió aquí Paschasio si él entendía que Laurencio era el más digno? No parece aver otra sino que, poner su dictamen viendo la voluntad de Dios y, como a su legítimo y verdadero prelado, endereçar a él todo aquel honor y reverencia que dava a Laurencio (pues el no hazerlo no dexava de redundar en menor honor y estimación de Sýmmaco). ¿Pues por esto á de estar tanto tiempo en Purgatorio un varón tan santo? ¿Y las limosnas, que apagan los pecados como el agua el fuego? ¿Y los milagros y tantas otras virtudes? Ya se le premiarán después, pero primero ha de purgar exactamente en Purgatorio la falta de reverencia a su prelado, aunque no sea más que indirecta o por omissión.

[9] 621. Concluyo con dezir que ni de la justicia ni de la misericordia se puede concebir aquí quexa alguna, porque aquella fue rectíssima mandando satisfazer el honor y reverencia del prelado con el medio necessario, connatural y más proporcionado (que fue el rendimiento de pedirle perdón) $y$, por otra parte, fue el devido cumplimiento de una santíssima ley que el mismo reo avía professado y estava obligado a cumplir. Y la misericordia resplandeció también aquí mucho dispensando benigníssimamente dos privilegios: el uno, permitiendo que bolviesse pedir perdón pudiéndolo dexar de hazer y que lo pagasse allá con más largo Purgatorio; el otro, en que bolviesse no después de horas, días ni años (como vemos suceder a otros) sino al mismo instante que espiró. En que se descubren los grandes méritos del bendito hermano, que merecieron le abreviasse Dios quanto fue possible el Purgatorio para que, cumplida brevemente esta obligación indispensable, volasse dichoso a celebrar en el Cielo con sus compañeros la gloria de sus triumfos. Que, si los antiochenos celebraran con annua festividad a santo Thomás monje porque con su oración hizo cessar la peste en su ciudad, estos la hizieron cessar en Bellpuyg no solo con sus oraciones sino con sus preciosas muertes, que celebrarían | ${ }^{184 b}$ mejor los del Cielo que los de la tierra..$^{5 *}$ 
24* De origen aragonés, fray José de Jesús María nació en 1533, y murió en el año 1601 en Lleida, donde había profesado en 1589. Todos estos datos biográficos son referidos por Beltrán Larroya, Gabriel 1986. Fuentes históricas de la provincia O. C. D. de San José (Cataluña y Baleares). Edición preparada por Gabriel Beltrán Larroya: 628 y 804. Roma: Teresianum. Al cual podría añadirse la informació que aporta fray Juan de San José en el ms. 991 (p. 185b-187 , § 628-633).

25* Tal como indican la mayor parte de las fuentes que refieren este episodio, entre otros fray Francisco de Santa María o el mismo fray Juan de San José en los capítulos inmediatamente anteriores (Mahiques, Joan 2014a: 193), el rector y prelado del colegio y convento de Lleida era fray Eutropio del Carmelo, llamado Miguel Fernández en este siglo. Nació en la localidad segoviana de Espinar en el año 1566, y murió en Corella en 1609. Profesó en Mataró el 1 de mayo de 1588. Fue ordenado sacerdote el 17 de marzo de 1590, siendo miembro de la comunidad de Tárrega; y llegó a ocupar el cargo de prior en los conventos de Tortosa y Lleida. Hemos reunido estos datos biográficos a partir de Beltrán Larroya 1986: 41, 48, 525 y 793.

26 Tal como hemos analizado en el apartado III, una buena parte de las autoridades que se refieren en este párrafo podrían inspirarse en Palafox y Mendoza 1661: 86, 21 y 323. En cambio, no hemos localizado la fuente de la cita puesta en boca de san Bernardo, que afirma temblar ante el juicio de Dios y tener por bueno un largo Purgatorio. Quizás pueda relacionarse con este tema la reflexión que san Bernardo incorpora al final de su sermón predicado con motivo de la muerte del monje Humberto: "Volat irrevocabile tempus, et dum creditis vos cavere poenam istam minimam, incurritis ampliorem. Illud enim scitote, quia post hanc vitam in purgabilibus locis centupliciter, quae fuerint neglecta, reddentur usque ad novissimum quadrantem" (San Bernardo 1968. S. Bernardi Opera vol. V: Sermones II. Ad fidem codicum recensuerunt J. Leclercq O.S.B., H. Rochais: 447, "In obitu domni Humerti", § 8. Romae: Editiones Cistercienses).

\section{${ }^{27^{*}}$ Cf. $M t$ 18: 23}

28 Cf. $M t$ 25: 36. Esta idea con las mismas palabras se encuentra en la regla de san Benito: “'Infirmorum cura ante omni et super omni adhibenda est, ut sicut revera Christo ita eis serviatur, quia ipse dixit: "Infirmus fuit et visitastis me', et: 'Quod fecistis uni de his minimis, mihi fecistis'” (Colombás, García M. / Aranguren, Iñaki ed. 1979. La Regla de San Benito. Introducción y comentario por García M. Colombás, monje benedictino. Traducción y notas por Iñaki Aranguren, monje cisterciense: 132, "XXXVI. De infirmis fratribus". Madrid: Biblioteca de Autores Cristianos).

${ }_{29}$ Cf. César Baronio 1864: 189, § 13 y 15. A través de esta autoridad, fray Juan de San José cita diversos fragmentos de una epístola escrita por san Dionisio, obispo de Alejandría que murió en 264/265. Sobre la biografía de este santo, remitimos a Bienert, Wolfgang A. 2006. "Dionisio de Alejandría”, en Diccionario enciclopédico de los santos. Biografías y conceptos básicos de culto. Tomo I: A-F: 410-411. Barcelona: Herder.

30 Cf. César Baronio 1864: 189, § 15. El ms. 990 no marca la laguna que nosotros hemos señalado entre corchetes.

31 Cf. Ibídem: 189-190, § 15 .

32 Cf. Ibídem: 190, § 16.

33* Cf. Ibídem 1589: 100. El Martirologio romano de César Baronio otorgaba distinción de mártires a los cristianos de Alejandría que, durante la epidemia de los años 249-263, coincidiendo con las persecuciones de diversos emperadores contra las comunidades cristianas, asistieron y reconfortaron a los enfermos y moribundos. Uno de los testimonios de dichos sucesos es precisamente san Dionisio. El mismo caso es aducido también en una obra que presenta bajo título de mártir al fundador de la Compañía de Jesús, según reza el "Capítulo XXXVIII. Cómo san Ignacio fue mártir por la caridad" (Nieremberg, Juan Eusebio 1645. Honor del gran patriarca san Ignacio de Loyola, fundador de la Compañía de lesvs, En que se propone su vida, y la de su Dicipulo el apostol de las Indias S. Francisco Xavier. Con la milagrosa Historia del admirable Padre Marcelo Mastrilli, y las noticias de gran multitud de Hijos del mismo S. Ignacio, varones clarissimos en santidad, dotrina, trabajos, y obras marauillosas en seruicio de la Iglesia: 95. Madrid: María de Quiñones).

34 Cf. Mt 25: 40-45.

35 Cf. Gregorio Magno 1978-1980: II, 370, liber III, caput XXVI, § 7.

36 Cf. Mt 20: 23.

37 Cf. Gregorio Magno 1978-1980: II, 372, liber III, caput XXVI, § 9.

38* No hemos localizado la fuente aducida por fray Juan de San José. Quizás pueda relacionarse con el pasaje que citamos en la nota 45, o con un sermón de san Agustín que trata sobre las maneras de pecado y su purificación antes y después de la muerte: "de quo dixit Apostolus, Ipse autem salvus erit, sic tamen quasi per ignem, non capitalia, sed minuta peccata purgantur. Et quamvis, quod pejus est, non solum majora, sed etiam minuta, si nimium plura sint, mergunt: de ipsis majoribus sive minoribus peccatis, etsi non omnia, vel aliqua commemoranda sunt, ne aliquis se inaniter excusare conetur, et dicat, nescire se quae sint minuta peccata, vel quae crimina capitalia" (Migne, J.-P. 1865. Patrologiae cursus completus seu bibliotheca universalis, integra, uniformis, commoda, oeconomica omnium ss. patrum, doctorum scriptorumque ecclesiasticorum, sive latinorum, sive graecorum [...] Patrologiae latinae tomus XXXIX, col. 1946, "Sermo CIV. De verbis Apostoli, I Cor. cap. III, 11-15. Fundamentum aliud nemo potest ponere, etc.", § 1. [Parisiis], J.-P. Migne editorem).

39 Cf. Jac 3:1-12.

40* Cf. Mt 5: 23-24.

41* Tal como hemos analizado en el apartado III, el ejemplo del Purgatorio de Taulerio podría inspirarse en Luz a los vivos y escarmiento en los muertos, cuyo autor es explícitamente aludido por fray Juan de San José al referirse a la satisfacción tanto de las deudas del honor como las de la hacienda (cf. Palafox y Mendoza 1661: 41 y 89-90). Sobre la enseñanza de santo Tomás de Aquino referente al bautismo de los adultos y a la necesidad de satisfacer o restituir deudas, remitimos al siguiente pasaje de la tercera parte de la Summa Theologiae, donde se responde a la objeción tercera del artículo quinto de la cuestión 68: "Ad tertium dicendum quod restituere male ablata proximis, et satisfacere de iniuriis illatis, est cessare a peccando, quia hoc ipsum quod est detinere aliena et proximum non placare, est peccatum. Et ideo peccatoribus baptizatis iniungendum est quod satisfaciant proximis, sicut et quod desistant a peccato. Non est autem eis iniungendum quod pro peccatis praeteritis aliquam poenam patiantur" (Corpus Thomisticum 2012. Corpus Thomisticum. S. Thomae de Aquino Opera Omnia. Recognovit ac instruxit Enrique Alarcón automato electronico: IIIa q. 68 a. 5 ad 3, § 50092. Pompaelone: ad Universitatis Studiorum Navarrensis, aedes a MMA.D. <http://www.corpusthomisticum.org/iopera.html>). Hemos consultado esta web en fecha de 05/06/2012.

42 Cf. Ps 117: 19-20.

43* Cf. $M t$ 3: 15.

44 Esta frase se refiere al siguiente pasaje de una carta de san Agustín a Macedonio: "Si enim res aliena, propter quam peccatum est, cum reddi possit, non redditur, non agitur poenitentia, sed fingitur: si autem veraciter agitur, non remittetur peccatum, nisi restituatur ablatum; sed, ut dixi, cum restitui potest" (Migne, J.-P. 1902. Patrologiae cursus completus, seu bibliotheca universalis, integra, uniformis, commoda, oeconomica, omnium ss. patrum, doctorum scriptorumque ecclesiasticorum, sive latinorum, sive graecorum [...] Patrologiae latinae tomus XXXIII, col. 662, "Epistola CLIII. Quaesito respondet; multa obiter disserens de restituendis rebus quae proximo ablatae vel male partae sunt", § 20. Parisiis: Apud Garnier fratres editores et J.-P. Migne successores). Esta sentencia forma parte del patrimonio común de la cultura cristiana occidental, y puede documentarse a través de diversos testimonios de lugares y épocas diferentes, como sucede en textos medievales citados por Soberanas, Amadeu-J. / Rossinyol, Andreu / Puig i Tàrrech, Armand 2001. Homilies d'Organyà. Facsímil del manuscrit. Edicions diplomàtica i crítica: Amadeu-J. Soberanas i Andreu Rossinyol. Amb un estudi d'Armand Puig i Tàrrech: 150-151. Barcelona: Barcino. Hernández, Francisco J. 2003. "La hora de don Rodrigo". Cahiers de linguistique et de civilisation hispaniques médiévales 26: 49. Por otra parte, los argumentos de fray Juan de San José se asemejan a los que desarrolla la Summa Theologiae a partir de la misma cita de san Agustín. A la objeción de que restituir lo quitado no es necesario para la salvación, la Summa opone la autoridad del obispo de Hipona, respondiendo después con la siguiente argumentación: "Sed contra est quod Augustinus dicit, non dimittitur peccatum, nisi restituatur ablatum. Respondeo dicendum quod restitutio, sicut dictum est, est actus iustitiae commutativae, quae in quadam aequalitate consistit. Et ideo restituere importat redditionem illius rei quae iniuste ablata est, sic enim per iteratam eius exhibitionem aequalitas reparatur. Si vero iuste ablatum sit, inaequalitas erit ut ei restituatur, quia iustitia in aequalitate consistit. Cum igitur servare iustitiam sit de necessitate salutis, consequens est quod restituere id quod iniuste ablatum est alicui, sit de necessitate salutis" (Corpus Thomisticum 2012: IIa-Ilae q. 62 a. 2 s. c. et co., § 41655-41656). 


\section{BibLIOgRAFía}

Arnall Juan, M. a Josepa 1986. “Aportación de los carmelitas descalzos a la cultura catalana", en El Carmelo teresiano en Cataluña. 15861986: 55-108. Burgos: Monte Carmelo.

Baschet, Jerôme 1993. Les justices de l'au-delà. Les représentations de l'enfer en France et en Italie (XIle-XVe siècle). Roma: École Française de Rome.

Beltrán Larroya, Gabriel 1986. Fuentes históricas de la provincia O. C. D. de San José (Cataluña y Baleares). Edición preparada por Gabriel Beltrán Larroya. Roma: Teresianum.

Bienert, Wolfgang A. 2006. "Dionisio de Alejandría”, en Diccionario enciclopédico de los santos. Biografías y conceptos básicos de culto. Tomo I: A-F. Barcelona: Herder.

Carrete Parrondo, Juan / Checa Cremades, Fernando / Bozal, Valeriano 1987. Summa Artis. Historia general del arte. Vol. XXXI: El grabado en España (siglos XVI al XVIII). Madrid: Espasa-Calpe.

César Baronio 1589. Martyrologivm Romanvm. Ad novam kalendarii rationem, et ecclesiasticae historiae veritatem restitvtem. Gregorii XIII. Pont. Max. ivssv editvm accesservnt notationes atque Tractatio Martyrologio Romanos: avctore Caesare Baronio Sorano. Antverpiae: Ex officina Christophori Plantini.

César Baronio 1864. Annales ecclesiastici denuo excusi et ad nostra usque tempora perducti ab Augustino Theiner. Tomus tertius: 253 317. Parisiis / Bruxellis: Barri-Ducis / Ludovicus Guérin.

Colombás, García M. / Aranguren, Iñaki (ed.) 1979. La Regla de San Benito. Introducción y comentario por García M. Colombás, monje benedictino. Traducción y notas por Iñaki Aranguren, monje cisterciense. Madrid: Biblioteca de Autores Cristianos.

Constitutiones 1787. Constitutiones fratrum discalceatorum beatissimae Virginis Mariae de Monte Carmelo primitivae observantiae. Congregationis Hispaniae, à SS. D. N. Pío Papa VI. Confirmatae die XIV. Martii Anno M.DCC.LXXXVI. Pontificatus sui anno duodecimo. Matriti: Ex Officina Josephi Doblado.

Corpus Thomisticum 2012. Corpus Thomisticum. S. Thomae de Aquino Opera Omnia. Recognovit ac instruxit Enrique Alarcón automato electronico. Pompaelone: ad Universitatis Studiorum Navarrensis, aedes a MMA.D. <http://www.corpusthomisticum.org/iopera. html>. Fecha de consulta: 05/06/2012.

Cortijo Ocaña, Antonio / Cortijo Ocaña, Adelaida 2003. "Vida de la madre Catalina de Cardona por fray Juan de la Miseria. Un texto hagiográfico desconocido del siglo XVI (Bancroft Library, UCB, Fernán Núñez Collection, vol. 143)". Dicenda. Cuadernos de filología hispánica 21: 21-34.

Duran, Eulàlia dir. / Toldrà, Maria coord. 2012. MCEM (Base de dades de Manuscrits Catalans de l'Edat Moderna). Barcelona: Institut

\section{Cf. Ps 104:15, y 1 Par 16:22.}

46* Cf. 1 Sam 15:22. La reflexión en torno a la obediencia en oposición a los sacrificios es uno de los puntos en los que la versión del ms. 991 (§ 619-620) desarrolla aspectos ausentes en el ms. 990. Debemos destacar que el ms. 991 no solamente cita la sentencia del Primer libro de Samuel, sino que también refiere el nombre de Saúl, cuyos holocaustos desagradaron a Dios a causa de su desobediencia. Y además, alude el caso de Catalina de Cardona (1519-1577), hija de Ramon Folc de Cardona-Anglesola, barón de Bellpuig, localidad donde murió precisamente fray Pedro de Jesús. Otra curiosa coincidencia se refiere a la tradición historiográfica de que el padre de Catalina de Cardona, poco después de morir, se apareció a ella cuando a penas tenía 8 años y le dijo que le atormentaban las llamas del Purgatorio. Este episodio ocupa el plano central de una estampa (dedicada toda ella a Catalina de Cardona) de la palabra Credenda de Francisco de la Cruz (1681: 12-13). Entre las numerosas fuentes que de una manera u otra establecen el perfil biográfico de esta terciaria carmelita, remitimos a Cortijo Ocaña, Antonio / Cortijo Ocaña, Adelaida 2003. "Vida de la madre Catalina de Cardona por fray Juan de la Miseria. Un texto hagiográfico desconocido del siglo xvi (Bancroft Library, UCB, Fernán Núñez Collection, vol. 143)”. Dicenda. Cuadernos de filología hispánica 21: 21-34.
d’Estudis Catalans. <http://mcem.iec.cat/>. Fecha de consulta: 05/04/2012.

Fournié, Michelle 1997. Le ciel peut-il attendre. Le culte du Purgatoire dans le Midi de la France (1320 environ - 1520 environ). Paris: Cerf.

Francisco de la Cruz 1681. Quarta palabra. Credenda. Aplicada al Purgatorio. Nápoles: Marco Antonio Ferro.

Francisco de la Cruz 1682. Quarta palabra. Credenda. Aplicada al Purgatorio. Nápoles: Marco Antonio Ferro.

Francisco de la Cruz 1687. Quarta parola dell'apostolo S. Paolo. Credenda. Applicata al Purgatorio. Napoli: Giuseppe Roselli.

Francisco de la Cruz 1691. Quarta parola dell'apostolo S. Paolo. Credenda. Applicata al Purgatorio. Napoli: Giuseppe Rosselli.

Francisco de la Cruz 1711. Quarta parola dell'apostolo S. Paolo. Credenda. Applicata al Purgatorio. Napoli: Felice Mosca.

Francisco de la Cruz 1724. Cinco palabras del apostol san Pablo comentadas por el Angelico Doctor santo Thomas de Aquino, y declaradas por el menor carmelita descalço fray Francisco de la Cruz, con doctrinas de su Madre Serafica santa Teresa de Jesus, y exemplos de su orden que dispiertan para vivir, y morir bien. Tomo segundo. Que contiene dos palabras: Credenda, Speranda. Valencia: Antonio Balle.

Francisco de santa María 1655. Reforma de los descalzos de Nvestra Señora del Carmen de la primitiva observancia, hecha Por santa Teresa de lesvs en la antiquissima Religion fundada por el gran Profeta Elias. Al eminentissimo i reverendissimo señor Cardenal D. Baltasar de Moscoso i Sandoval, Arçobispo de Toledo, \&c. Por el Padre Fray Francisco de Santa Maria su General Historiador, natural de Granada. Tomo Segvndo. Madrid: Diego Diaz de la Carrera.

Gras Casanovas, Mercè 2014. Diccionari biogràfic d'autors carmelites descalços de la Província de Sant Josep, en MCEM (Base de dades de Manuscrits Catalans de l'Edat Moderna). Barcelona: Institut d'Estudis Catalans. <http://mcem.iec.cat/biografia.asp?id=64> $<$ http://mcem.iec.cat/biografia.asp?id=150>. Fecha de consulta: 20/12/2014.

Gregorio Magno 1978-1980. Dialogues. [I: Introduction, bibliographie et cartes par Adalbert de Vogüé]. [II: Livres I-III. Texte critique et notes par Adalbert de Vogüé. Traduction par Paul Antin]. [III: Livre IV. Texte critique et notes par Adalbert de Vogüé. Traduction par Paul Antin]. Paris: Cerf.

Hernández, Francisco J. 2003. "La hora de don Rodrigo". Cahiers de linguistique et de civilisation hispaniques médiévales 26: 15-71.

Mahiques, Joan 2014a. "Tres carmelites descalços durant la pesta de Bellpuig: reescriptures d'un passatge historiogràfic". Urtx. Revista cultural de I’Urgell 28: 187-204.

47* Cf. Gregorio Magno 1978-1980: III, 150-154, liber IV, caput XLII.

48 Cf. Ibídem: III, 156, liber IV, caput XLIII, § 4.

${ }_{49 *}$ Cf. Constitutiones 1787. Constitutiones fratrum discalceatorum beatissimae Virginis Mariae de Monte Carmelo primitivae observantiae. Congregationis Hispaniae, à SS. D. N. Pío Papa VI. Confirmatae die XIV. Martii Anno M.DCC.LXXXVI. Pontificatus sui anno duodecimo: 37, “Caput V. De obedientiae voto stricte servando", § 9. Matriti: Ex Officina Josephi Doblado.

50* $\quad$ Este pasaje se refiere a santo Tomás de Emesa, antiguo topónimo que se corresponde a la actual ciudad siria de Homs: "Tomás murió [...] como víctima de la peste y fue sepultado en una fosa común. Pero como los cuerpos sobre los cuales se depositó su cadáver fueron expulsados de la tumba como por un milagro, se informó de los hechos al obispo Efraín (527-545), que hizo trasladar los restos de Tomás al cementerio de Antioquía. En ese momento terminó la epidemia de peste que azotaba Antioquía, y el milagro fue atribuido a la intercesión de Tomás [...] La epidemia de peste de la cual se habla pudo ser con gran probabilidad la del año 542, de modo que el día de su conmemoración habría sido introducido entre 542 y 545 (año de la muerte de Efraín)" (Zanetti, Ugo 2006. "Tomás de Emesa" en Diccionario enciclopédico de los santos. Biografías y conceptos básicos de culto. Tomo III: P-Z: 622623. Barcelona: Herder). 
Mahiques, Joan 2014b. "Tres carmelites descalços durant la pesta de Bellpuig: declaracions jurades". Analecta Sacra Tarraconensia 87: 191-219.

Migne, J.-P. 1865. Patrologiae cursus completus seu bibliotheca universalis, integra, uniformis, commoda, oeconomica omnium ss. patrum, doctorum scriptorumque ecclesiasticorum, sive latinorum, sive graecorum [...] Patrologiae latinae tomus XXXIX. [Parisiis]: J.-P. Migne editorem.

Migne, J.-P. 1902. Patrologiae cursus completus, seu bibliotheca universalis, integra, uniformis, commoda, oeconomica, omnium ss. patrum, doctorum scriptorumque ecclesiasticorum, sive latinorum, sive graecorum [...] Patrologiae latinae tomus XXXIII. Parisiis: Apud Garnier fratres editores et J.-P. Migne successores.

Miquel Rosell, Francisco 1958. Inventario general de manuscritos de la Biblioteca Universitaria de Barcelona. II: 501 a 1000. Madrid: Direcciones Generales de Enseñanza Universitaria y de Archivos y Bibliotecas / Servicio de Publicaciones de la Junta Técnica.

Nieremberg, Juan Eusebio 1645. Honor del gran patriarca san Ignacio de Loyola, fvndador de la Compañía de lesvs, En que se propone su vida, y la de su Dicipulo el apostol de las Indias S. Francisco Xavier. Con la milagrosa Historia del admirable Padre Marcelo Mastrilli, y las noticias de gran multitud de Hijos del mismo S. Ignacio, varones clarissimos en santidad, dotrina, trabajos, y obras marauillosas en seruicio de la Iglesia. Madrid: María de Quiñones.

Palafox y Mendoza, Juan de 1661. Lvz a los vivos. Y escarmiento en los mvertos. Por el ilvstrissimo, y Reuerendissimo Señor Don luan de Palafox y Mendoza, Obispo de Osma, del Consejo del Rey N. Señor. Madrid: María de Quiñones.
Palau y Dulcet 1967. Manual del librero hispanoamericano. Bibliografía general española e hispanoamericana desde la invención de la imprenta hasta nuestros tiempos con el valor comercial de los impresos descritos. Segunda Edición, corregida y aumentada por el autor. Tomo XIX: San - Santa (289221-299369). Barcelona: Librería Palau.

Puig, Isidre / Company, Ximo 2009. Els carmelites descalços a Lleida. El convent de Sant Josep. Lleida: Museu de Lleida.

Ripoll Villamajó, Jaume 1820 = J. R. V. Compendio de la vida y virtudes del ven. P. Fr. Juan de la Virgen, carmelita descalzo natural de la villa de Bellpuig, y de otros tres carmelitas descalzos que dieron sus vidas asistiendo a los apestados de la misma villa: sacado de los Anales mm. de los pp. carmelitas descalzos de Cataluña, y publicado con algunas notas por D. J. R. V. Vic: Ignacio Valls.

Rodríguez Barral, Paulino 2007. La justicia del más allá. Iconografía en la Corona de Aragón en la Baja Edad Media. Valencia: Universitat de València.

San Bernardo 1968. S. Bernardi Opera vol. V: Sermones II. Ad fidem codicum recensuerunt J. Leclercq O.S.B., H. Rochais. Romae: Editiones Cistercienses.

Soberanas, Amadeu-J. / Rossinyol, Andreu / Puig i Tàrrech, Armand 2001. Homilies d'Organyà. Facsímil del manuscrit. Edicions diplomàtica i crítica: Amadeu-J. Soberanas i Andreu Rossinyol. Amb un estudi d'Armand Puig i Tàrrech. Barcelona: Barcino.

Toda y Güell, Eduart 1928. Bibliografia espanyola d'Italia dels origens de la imprempta fins a l'any 1900 per Eduart Toda y Güell. Volum II: D-L. Castell de sant Miquel d’Escornalbou: [Imp. Vidal Güell].

Zanetti, Ugo 2006. "Tomás de Emesa" en Diccionario enciclopédico de los santos. Biografías y conceptos básicos de culto. Tomo III: P-Z. Barcelona: Herder. 